\title{
Northern spotted owl nesting forests as fire refugia: a 30-year synthesis of large wildfires
}

\author{
Damon B. Lesmeister ${ }^{1,2^{*}}$ (D) Raymond J. Davis ${ }^{3}$, Stan G. Sovern ${ }^{1,2}$ and Zhiqiang Yang ${ }^{4}$
}

\begin{abstract}
Background: The northern spotted owl (Strix occidentalis caurina) is an Endangered Species Act-listed subspecies that requires coniferous forests with structurally complex and closed-canopy old-growth characteristics for nesting. With climate change, large wildfires are expected to become more common within the subspecies' range and an increasing threat to these types of forests. Understanding fire severity patterns related to suitable nesting forest will be important to inform forest management that affects conservation and recovery. We examined the relationship between fire severity and suitable nesting forest in 472 large wildfires (> 200 ha) that occurred in the northern spotted owl range during 1987-2017. We mapped fire severities (unburned-low, moderate, high) within each fire using relative differenced normalized burn ratios and quantified differences in severity between pre-fire suitable nesting forest (edge and interior) and non-nesting forest. We also quantified these relationships within areas of three fire regimes (low severity, very frequent; mixed severity, frequent; high severity, infrequent).

Results: Averaged over all fires, the interior nesting forest burned at lower severity than edge or non-nesting forest. These relationships were consistent within the low severity, very frequent, and mixed severity, frequent fire regime areas. All forest types burned at similar severity within the high severity, infrequent fire regime. During two of the most active wildfire years that also had the largest wildfires occurring in rare and extreme weather conditions, we found a bimodal distribution of fire severity in all forest types. In those years, a higher amount-and proportionof all forest types burned at high severity. Over the 30-year study, we found a strong positive trend in the proportion of wildfires that burned at high severity in the non-nesting forests, but not in the suitable nesting forest types.

Conclusions: Under most wildfire conditions, the microclimate of interior patches of suitable nesting forests likely mitigated fire severity and thus functioned as fire refugia (i.e., burning at lower severity than the surrounding landscape). With changing climate, the future of interior forest as fire refugia is unknown, but trends suggest older forests can dampen the effect of increased wildfire activity and be an important component of landscapes with fire resiliency.
\end{abstract}

Keywords: Northern spotted owl, Strix occidentalis caurina, Wildfire severity, RdNBR, Climate change, Fire refugia

\footnotetext{
* Correspondence: damon.lesmeister@usda.gov

'USDA Forest Service, Pacific Northwest Research Station, 3200 NW Jefferson

Way, Corvallis, OR 97331, USA

2Department of Fisheries, Wildlife, and Conservation Sciences, Oregon State

University, Corvallis, OR 97331, USA

Full list of author information is available at the end of the article
}

\section{Springer Open}

(c) The Author(s). 2021 Open Access This article is licensed under a Creative Commons Attribution 4.0 International License, which permits use, sharing, adaptation, distribution and reproduction in any medium or format, as long as you give appropriate credit to the original author(s) and the source, provide a link to the Creative Commons licence, and indicate if changes were made. The images or other third party material in this article are included in the article's Creative Commons licence, unless indicated otherwise in a credit line to the material. If material is not included in the article's Creative Commons licence and your intended use is not permitted by statutory regulation or exceeds the permitted use, you will need to obtain permission directly from the copyright holder. To view a copy of this licence, visit http://creativecommons.org/licenses/by/4.0/. 


\section{Resumen}

Antecedentes: La lechuza moteada del norte (Strix occidentalis caurina) es una subespecie listada como en peligro de extinción por la ley sobre especies amenazadas, ya que requiere de bosques de coníferas con características estructurales complejas, doseles cerrados y prístinos para poder anidar. Con el cambio climático, se espera que los grandes incendios sean más comunes dentro del hábitat de la subespecie y se incremente la amenaza a estos tipos de bosques. Entender los patrones de severidad del fuego relacionados con las condiciones apropiadas para anidar en el bosque podrían ser muy importantes para informar al manejo forestal que se ocupa de la conservación y la recuperación. Examinamos la relación entre la severidad del fuego y las condiciones apropiadas para anidar en el bosque en 472 grandes incendios (> 200 ha), que ocurrieron en el hábitat de la lechuza moteada del norte entre 1987-2017. Mapeamos distintas severidades del fuego (sin quemar, bajo, moderado, alto) dentro de cada incendio, utilizando relaciones de diferencias relativas normalizadas, y cuantificamos las diferencias de severidad entre bosques con condiciones apropiadas antes del fuego (borde e interior) y bosques sin condiciones para anidar. También cuantificamos estas relaciones entre áreas de tres regímenes de fuego (severidad baja, muy frecuente; severidad mixta, frecuente; y severidad alta, infrecuente).

Resultados: Promediando todos los fuegos, la parte interior del bosque para anidar se quemó a más baja intensidad que en el borde exterior o en el bosque no apto para anidar. Estas relaciones fueron consistentes dentro de áreas con régimen de fuegos frecuentes dentro de la severidad baja, muy frecuente, y severidad mixta. Dentro del régimen de fuegos infrecuente de alta severidad, todos los tipos de bosque se quemaron con una severidad similar. Durante dos de los años más activos de incendios, que también presentaron los fuegos más grandes y que ocurrieron en condiciones meteorológicas extremas y raras, encontramos una distribución bimodal de severidad del fuego en todos los tipos de bosque. En esos años, una cantidad más grande -y proporción - de todos los tipos de bosque se quemaron a altas severidades. Durante los 30 años de estudio, encontramos una fuerte tendencia positiva de fuegos que quemaron a altas severidades en los bosques no aptos para anidar, pero no en los tipos de bosque apropiados para anidar.

Conclusiones: Bajo la mayoría de las condiciones de fuego, el microclima del interior de los parches en bosques apropiados para anidar, probablemente mitigaron la severidad del fuego y así funcionaron como refugios de fuego (por ej., quemando a severidades más bajas que el paisaje de alrededor). Con el cambio en el clima, el futuro del bosque interior como refugios de fuego se desconoce, pero las tendencias sugieren que los bosques prístinos pueden aminorar el efecto de la actividad en incremento de los fuegos y ser un componente importante de paisajes con resiliencia al fuego.

\section{Background}

The effect of wildfire on individual species and wildlife communities can range from highly beneficial to strongly negative depending on species-specific adaptability to disturbance and fire characteristics such as vegetation type burned, fire size, return interval, seasonality, and severity (Smith 2000). For example, many wildfires can be beneficial for some avian species (e.g., woodpeckers) because post-fire conditions enhance forage and nesting opportunities (Hutto 2008), but wildfire can remove many important habitat requirements for other species (e.g., greater sage-grouse Centrocercus urophasianus) (Coates et al. 2015; Foster et al. 2019). It is common within large wildfires to have a mix of fire severities, ranging from unburned-to-low severity to areas with nearly complete mortality of forest vegetation (high severity). For many forest-adapted species, the effects of wildfire trend more negatively with increasing severity, such that low severity being neutral or beneficial and high-severity fire negatively affecting species (Fontaine and Kennedy 2012). At the population scale, negative effects of high severity wildfire can be serious for forest wildlife facing extinction or extirpation. For example, wildfires in Australia in 2020 burned critical habitat for as many as 100 threatened species (Pickrell and Pennisi 2020), and wildfire is listed as one of the main threats to greater sage-grouse habitat, though rangewide habitat has been fragmented from other causes (USFWS 2015).

The northern spotted owl (Strix occidentalis caurina) inhabits coniferous forests of the Pacific Northwest of North America. It requires late-successional, multistoried, closed-canopy forests with large trees for nesting, roosting, and foraging (Forsman et al. 1984; Wilk et al. 2018; Sovern et al. 2019). Barred owls (Strix varia) also inhabit these forests and are an important competitor and severe threat to northern spotted owls (Wiens et al. 2014; Jenkins et al. 2019b; Yackulic et al. 2019; Wiens et al. 2021). Due primarily to loss of older forests from timber harvest, the northern spotted owl was listed as threatened in 1990 under the US Endangered Species 
Act (USFWS 1990). The Northwest Forest Plan (NWFP) was then designed and has been implemented in part to conserve and recover enough late-successional forest on federally administered lands to support recovery of the subspecies (USDA and USDI 1994). The standards and guidelines of the NWFP on federal lands have been critical to northern spotted owl conservation but further management interventions are likely needed for successful population recovery (Lesmeister et al. 2018). Due primarily to continued loss of old forest and barred owl competition, northern spotted owl populations have continued to decline since the mid-1990s (Franklin et al. 2021) and were found to warrant reclassification to endangered in 2020 (USFWS 2020). Older forests that are suitable for nesting by northern spotted owls are monitored as a component of the NWFP effectiveness monitoring program (e.g., Davis et al. 2016). Based largely on NWFP monitoring results, large wildfires have been identified as one of the primary and increasing threats affecting northern spotted owl habitat (Lesmeister et al. 2018), and the occurrence and extent of large wildfires in the Western US is predicted to increase due to climate change (Westerling et al. 2006; Abatzoglou and Williams 2016; Davis et al. 2017; Wan et al. 2019).

High-severity fire, especially when combined with post-fire salvage logging, resets forest succession (e.g., Thompson et al. 2007) and removes forest cover suitable for nesting by northern spotted owls, resulting in negative effects on territory occupancy and survival (Clark et al. 2011; Clark et al. 2013; Rockweit et al. 2017; Lesmeister et al. 2019). Conversely, low severity fire has little effect on species composition or structure of suitable nesting forest, and vital rates are not altered (Rockweit et al. 2017; Lesmeister et al. 2019). Mixed-severity fires in landscapes with extensive northern spotted owl habitat result in diffuse forest edges that are preferentially selected for foraging and thus potentially beneficial to populations (Comfort et al. 2016). In a relatively coarsescale analysis throughout the western USA, Bradley et al. (2016) found that fire severity was lower on lands with less active management which generally corresponded to more mature forests and higher biomass and fuel loading. For one mixed-severity wildfire that burned in a mixed-ownership landscape during a drought year and with severe fire weather conditions, younger forests (mean age 52.2 years) that were intensively managed for timber production burned at higher severity than older forests (mean age 108.8 years) with complex structure and designated as late-successional reserves under the NWFP (Zald and Dunn 2018). In that same fire complex, Lesmeister et al. (2019) found that northern spotted owl nesting forest with old forest characteristics had the lowest odds of burning at high severity compared to other forest types. However, it is unknown if those patterns of burn severity related to suitable nesting forest and management were unique to that landscape and those weather conditions, and perhaps findings would differ if many fires occurring over many years were included in the analyses.

Fire refugia can be defined as landscape elements that remain unburned, burn less frequently, or burn at lower severity than the surrounding landscape (Meddens et al. 2018). We sought to determine if northern spotted owl nesting forest may be considered fire refugia by burning at lower severity than non-nesting forest types (i.e., surrounding landscape) over many large wildfires that occurred during a 30-year period. Understanding the patterns of fire severity as related to the different forest types and spatial patterns over the entire range of the northern spotted owl can provide valuable information on how best to manage those forests for the subspecies' conservation and recovery. Forests used by northern spotted owls for nesting (i.e., suitable nesting forest) have old-growth characteristics that are typically older coniferous forests with large trees and moderate to closed canopy (Forsman et al. 1984). Non-nesting forests were distinct from suitable nesting forest in species composition or structure, or both (Franklin and Dyrness 1973; Swanson et al. 2011; Lesmeister et al. 2018; Spies et al. 2018). We mapped edge and interior suitable nesting forest and non-nesting forest for each year of the three-decade study and quantified wildfire severity in each of the three forest types across all large wildfires rangewide and within each of the three fire regimes of the region.

To elucidate the role northern spotted owl nesting forest may have played as fire refugia, our objectives were to (1) examine the pre-fire pattern of suitable nesting forest in relation to observed wildfire severity, (2) compare wildfire severity between suitable nesting forest and other forest types in the fire perimeter, and (3) examine temporal trends in wildfire severity in each forest type over the duration of the study. Compared to other forest types, the interior portions of old forest ( $>30 \mathrm{~m}$ from an edge) can have milder microclimates during summer with lower wind speeds and temperature, and higher humidity (Chen et al. 1995). Therefore, we hypothesized that interior nesting forest would function as fire refugia by burning at lower fire severities compared to other forest types during large wildfires but that this relationship would be less prominent in the low severity, very frequent fire regime areas due to more rapid drying of vegetation during fire seasons.

\section{Methods}

Study area

We conducted our study of wildfire severity within the USA portion of the range of northern spotted owls (Fig. 
(a)

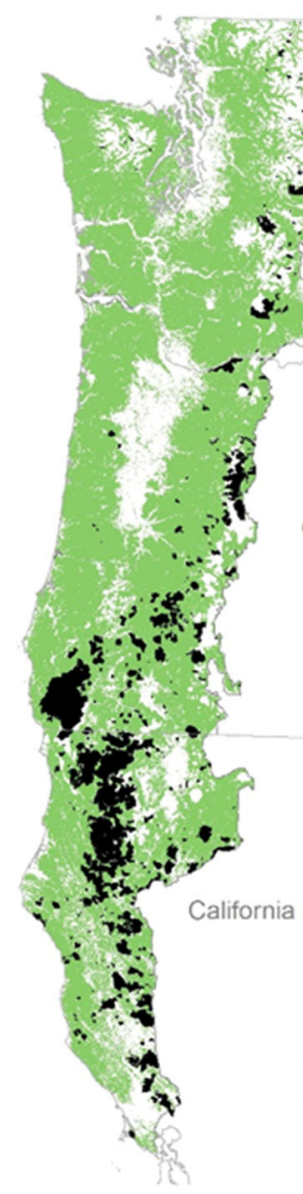

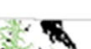
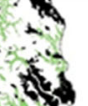

(1)

Washington

Oregon

Range of the

Northern Spotted Owl

Habitat capable forest

Large wildfires (>200ha)

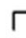

(b)

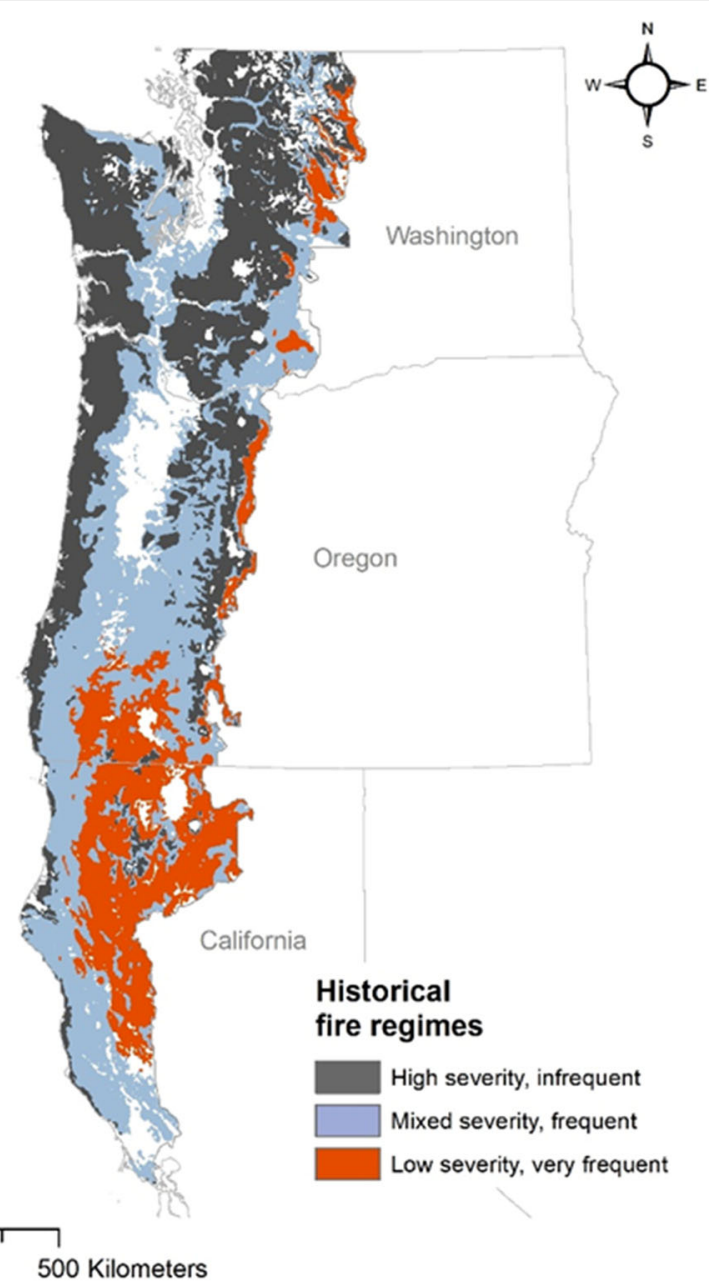

Fig. 1 The range of the northern spotted owl range in the USA. Map a: potential nesting forest (i.e., habitat capable forest) and coverage of large (> 200 ha) wildfires from 1987 to 2017. Potential nesting forests were those areas with environmental conditions of elevation $(<2000 \mathrm{~m})$ and soil types that without disturbance (e.g., timber harvest) could develop into suitable forest for nesting and roosting by spotted owls given time for succession. Map b: the extent of three historical fire regimes modified from Spies et al. (2018). The high severity, infrequent regime are those areas that typically experience large to very large patches of high-severity fire on $>200$-year return intervals. The mixed severity, frequent regime were those areas typically burning with a relatively even mix of severity and relatively frequent return interval (15-200 years). Prior to effective fire exclusion during the past century the low severity, very frequent regime areas would have experienced short return intervals (5-25years) and were dominated by low-severity fire

1). Within this area, 472 large wildfires ( $>200$ ha) occurred from 1987 to 2017 over the full range of fire regimes extending across approximately $162,000 \mathrm{~km}^{2}$ from western Washington to northwest California (Fig. 1a). A diversity of forest ecosystems composed the study area, with old-growth conifer forests being the most common climax communities. The major biophysical driving variables of extent, structure, composition, and dynamics of these old-growth forests were climate, topography, soils, succession processes, and disturbance events (Franklin and Dyrness 1973; Oliver 1981). Historically, landform, soil conditions, and relatively stable regional climate resulted in somewhat predictable biotic communities, pathways of forest development, levels of ecosystem productivity, and spatial patterns of disturbance regimes (Franklin and Dyrness 1973).

An area's fire regime is most strongly influenced by the normal frequency and severity of wildfires but is complex and can include area burned, spatial distribution of fire, fire season, and duration of burning (Agee 1993; Reilly et al. 2017; Sugihara et al. 2018). Spies et al. (2018) mapped four historical fire regimes within the NWFP area: infrequent-high severity, moderately frequent-mixed severity, frequent-mixed severity, and very frequent-low severity. We used this fire regime classification to explore the relationship between fire severity and suitable nesting forest rangewide and for each fire regime (Fig. 1b). Given burn pattern similarities in 
the two mixed-severity regimes, we combined them as the mixed severity, frequent regime for our analyses. The other regimes we termed as high severity, infrequent and low severity, very frequent. The high severity, infrequent regime were those areas experiencing $>200$ year return intervals with large to very large patches of high-severity and stand-replacing fire. The mixed severity, frequent regime were those areas with a relatively frequent return interval (15-200 years) and wildfires typically burning with mixed severity and medium to large patches of high-severity fire. Prior to effective fire exclusion during the past century the low severity, very frequent regime would have experienced short return intervals (5-25 years) and been dominated by lowseverity fire with large high-severity patches rarely occurring (Agee 1993; Spies et al. 2018). The extent and frequency of wildfires throughout the duration of our analyses indicated that fire was less common in the low severity, very frequent regime than would be expected under historical fire regimes (Spies et al. 2018).

\section{Forest type classification}

Forests used by northern spotted owls for nesting and roosting are typically more than 125 years of age with average tree diameters at breast height $>50 \mathrm{~cm}$ (often high diversity of sizes and some trees are $>75 \mathrm{~cm}$ diameter) and multi-layered canopies with $>60 \%$ canopy cover (Davis et al. 2016). Here we refer to this as suitable nesting forest, which differed in species composition or structure, or both, from the surrounding landscape consisting of other forest types (Franklin and Dyrness 1973; Franklin and Hemstrom 1981; Swanson et al. 2011). Within the study area, there were large areas not capable of developing into suitable nesting forest, mainly due to soil type, plant association, or elevation (Davis and Lint 2005). Therefore, we restricted our classification of forest types to potential nesting forest areas which had the capability (e.g., suitable abiotic and biotic characteristics) to develop into suitable nesting forest in the absence of disturbances that reset successional stage (Fig. 1a).

Information on pre-fire forest species composition and structure is critical for examining relationships between forest types and wildfire effects (Meigs and Krawchuk 2018; Lesmeister et al. 2019). We used newly developed maps of suitable nesting forests that were generated by the NWFP northern spotted owl habitat monitoring program (Davis et al. In Press). These monitoring maps have been used in many publications on northern spotted owl population dynamics and resource selection (e.g., Wiens et al. 2014; Dugger et al. 2016; Jenkins et al. 2019a; Franklin et al. 2021; Jenkins et al. 2021). Suitable nesting forest maps were produced using open source software Maxent (Phillips et al. 2006; Phillips et al. 2017) following NWFP monitoring methods (Fig. 1a, Davis et al. 2011; Davis et al. 2016). The maps were evaluated for predictive accuracy using nesting/roosting owl pair locations that were held out from the modeling. Models predicted these test locations well with Area Under the Curve estimates ranging from 0.78 to 0.92 and predicted versus expected ratio curve Spearman rank correlation coefficients from 0.87 to $0.98(P<0.001$; Fielding and Bell 1997; Hirzel et al. 2006; Davis et al. In Press). Using Google Earth Engine (Gorelick et al. 2017), we applied suitable nesting forest algorithms to Landsat-based (30 $m$ pixel resolution) annual time series (1987-2017) of forest structure and species composition maps (Bell et al. 2021). The resulting dynamic annual maps of suitable nesting forest spanned all years analyzed here, which we classified into binary maps of suitable nesting forest and used program GUIDOS (Soille and Vogt 2009) to classify suitable nesting forest pixels as either INTERIOR or EDGE forest (Fig. 2). The INTERIOR forest pixels were $>30 \mathrm{~m}$ from NON-NESTING forest and the EDGE forest pixels were adjacent to $\geq 1 \mathrm{NON}$ NESTING forest pixel(s). The NON-NESTING pixels were within the potential nesting forest area but not suitable for nesting because they were primarily younger forests, thinned older forest, or pre-forest conditions (Table 1) (Davis et al. 2016; Davis et al. In Press). The smallest patch size of suitable nesting forest that could contain an INTERIOR class was a $3 \times 3$ pixel configuration $(0.81 \mathrm{ha})$, large enough to contain microclimates distinct from NON-NESTING forests (Heithecker and Halpern 2007). We summarized forest age and structure metrics for each forest type within each historical fire regime using data generated through gradient nearest neighbor imputation mapping, which is a multivariate analysis of forest inventory, remote sensing, and environmental data and is the standard tool for forest structure and species composition mapping and monitoring in the Pacific Northwest (Ohmann and Gregory 2002; Bell et al. 2021).

\section{Wildfire data}

Northern spotted owl territories are on average 700 ha (range 180 to 1390 ha) in size (Dugger et al. 2016), so we focused on wildfires that were $\geq 200$ ha in size, large enough to impact $>25 \%$ of an average territory. Based on these criteria, we used 472 wildfires that totaled $20,970 \mathrm{~km}^{2}$, with $17,273 \mathrm{~km}^{2}$ burned in the extent of potential nesting forests (Fig. 3). This allowed us to examine fire severity encompassing various forest types and arrangements, as well as temporal trends in severity over a 30-year period.

We used a Landsat-based time series (1986-2017) of forest disturbance maps produced by the Landscape Change Monitoring System (LCMS; Healey et al. 2015) to measure extent and severity of wildfire. LCMS data 


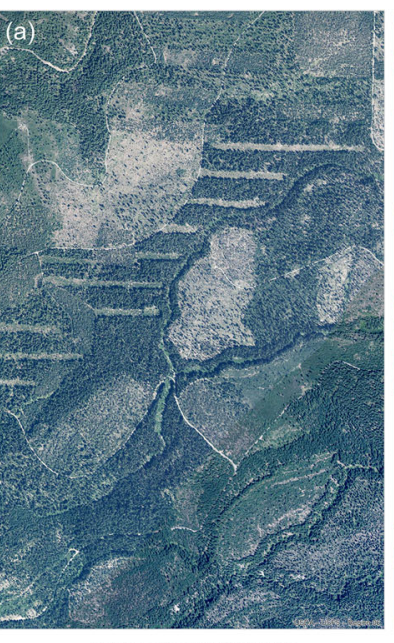

High-resolution aerial imagery

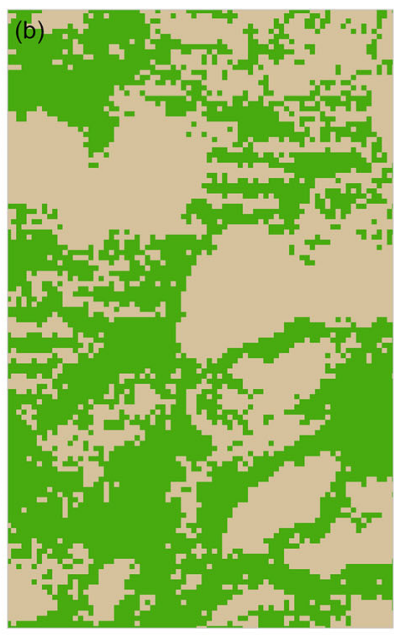

Binary map of nesting forest cover types $\square$ NON-NESTING NESTING

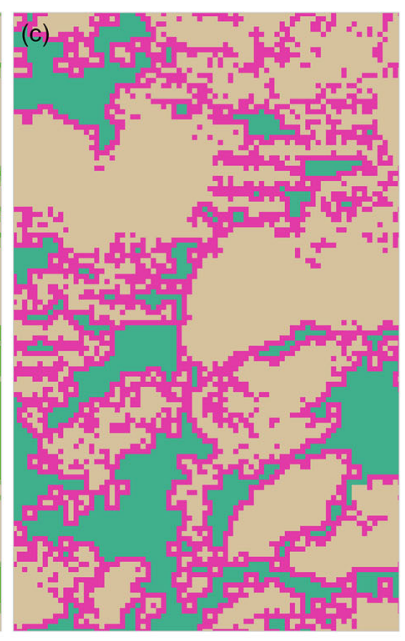

Edge and interior nesting cover type spatial patterns

$\square$ NON-NESTING $\square$ EOGE $\square$ INTERIOR

Fig. 2 Maps of forests that are suitable for nesting and roosting by northern spotted owls. Map a: high-resolution aerial imagery of an area with clear-cuts, younger forest, closed-canopy old forest, and thinned old forest. Map $\mathbf{b}$ : the same area with an example binary map identifying nesting forest and non-nesting forest. Map c: same area showing nesting forest classified as edge and interior pixels

are analogous to Monitoring Trends in Burn Severity (MTBS) but calibrated to local conditions and available for all wildfires in our time series. LCMS maps used forest disturbance data collected with TimeSync software (Cohen et al. 2010) and an ensemble LandTrendr disturbance mapping algorithm (Cohen et al. 2018; Healey et al. 2018) to produce annual disturbance maps with magnitude quantified by relativized difference in the normalized burn ratio (RdNBR) (Miller and Thode 2007). We used Reilly et al. (2017) classifications of fire severity based on RdNBR within fire perimeters for unburned-low (RdNBR $<235,<25 \%$ basal area mortality), moderate (RdNBR 235-649, 25-75\% basal area mortality), and high ( $\operatorname{RdNBR} \geq 649,>75 \%$ basal area mortality) severity classes (Additional file 1: Appendix $1)$.

\section{Wildfire selection ratios}

We selected wildfires with $\geq 50 \%$ of the forested area within their perimeters classified as potential nesting forest $\left(n=472 ; 17,273 \mathrm{~km}^{2}\right)$ to compare fire severity relationships between INTERIOR, EDGE, and NONNESTING forest types. Most wildfires had $>90 \%$ of the area within their perimeter classified as potential nesting forest. We used selection ratios (Manly et al. 2002) to compare wildfire severity in our three forest types, taking into account the proportion of each forest type within each wildfire perimeter (Moreira et al. 2001;

Table 1 Mean (standard deviation) of forest age and structure metrics within forest types (NON-NESTING, EDGE, INTERIOR) of potential nesting forests for northern spotted owls by fire regime [high severity, infrequent (HIGH); mixed severity, frequent (MIXED); low severity, very frequent (LOW)]

\begin{tabular}{|c|c|c|c|c|c|c|c|c|c|}
\hline \multirow{2}{*}{$\begin{array}{l}\text { Stand structure } \\
\text { metrics }\end{array}$} & \multicolumn{3}{|c|}{ NON-NESTING } & \multicolumn{3}{|l|}{ EDGE } & \multicolumn{3}{|c|}{ INTERIOR } \\
\hline & HIGH & MIXED & LOW & $\mathrm{HIGH}$ & MIXED & LOW & HIGH & MIXED & LOW \\
\hline Stand age ${ }^{a}$ & $59(54)$ & $63(41)$ & $81(34)$ & $155(86)$ & $125(68)$ & $122(46)$ & $212(83)$ & $184(77)$ & $153(48)$ \\
\hline Canopy cover $^{\mathrm{b}}$ & $59(28)$ & $47(26)$ & $36(22)$ & $80(14)$ & $68(17)$ & $60(15)$ & $85(9)$ & $74(13)$ & $63(12)$ \\
\hline Live conifer d.b.h. ${ }^{c}$ & $33(21)$ & $36(21)$ & $39(18)$ & $61(24)$ & $60(24)$ & $59(20)$ & $71(22)$ & $72(22)$ & $72(20)$ \\
\hline Diameter diversity ${ }^{d}$ & $3(2)$ & $3(2)$ & $4(2)$ & $6(2)$ & $6(1)$ & $6(1)$ & $7(1)$ & $7(1)$ & $7(1)$ \\
\hline Stand height ${ }^{\mathrm{e}}$ & $18(10)$ & $17(9)$ & $14(6)$ & $31(10)$ & $27(10)$ & $22(7)$ & $35(8)$ & $34(9)$ & $27(7)$ \\
\hline Large conifer density ${ }^{f}$ & $4(10)$ & $4(8)$ & $4(7)$ & $22(19)$ & $18(16)$ & $15(12)$ & $31(18)$ & 30 (18) & $24(14)$ \\
\hline
\end{tabular}

${ }^{a}$ Average stand age based on field-recorded ages of live dominant and codominant trees

${ }^{b}$ Percent canopy cover of live conifer trees

'Diameter $(\mathrm{cm})$ at breast height of live conifer trees

${ }^{d}$ Index of structural diversity based on live conifer tree densities in different diameter classes (Davis et al. 2016)

${ }^{\mathrm{e}}$ Average height $(\mathrm{m})$ of live dominant and codominant trees

fDensity (trees/ha) of large ( $>75 \mathrm{~cm}$ d.b.h.) live conifer trees 


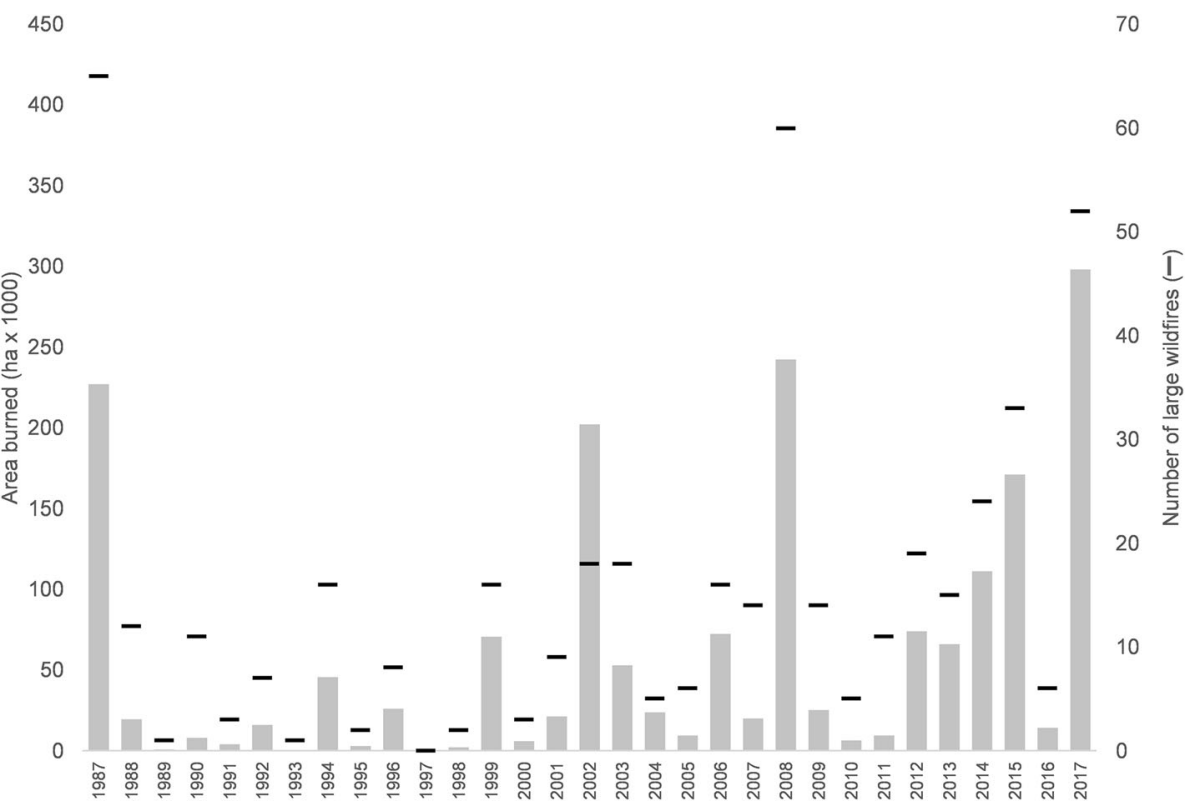

Fig. 3 Total area of potential nesting forest that burned each year during large wildfires ( $\geq 200 \mathrm{ha})$. Potential nesting forests were those areas with environmental conditions of elevation (below $2000 \mathrm{~m}$ ) and soil types that without disturbance (e.g., timber harvest) could develop into suitable forest for nesting and roosting by spotted owls given time for succession. On secondary $y$-axis are the number of large wildfires per year (black markers) within the range of the northern spotted owl, USA, 1987-2017

Moreira et al. 2009; Lesmeister et al. 2019). We defined our selection ratios as the area burned:area available for burning $(\mathrm{B} / \mathrm{A})$ ratio. We estimated $\mathrm{B} / \mathrm{A}$ for forest type $i$ burning at severity class $j\left(w_{i j}\right)$ by $w_{i j}=o_{i j} / \pi_{i}$, where $o_{i j}$ $=$ the proportion area burned at severity $j$ that was forest type $i$, and $\pi_{i}$ is the proportion of forest type $i$ available to burn (i.e., within wildfire perimeter). Values for $w_{i j}=$ 1 indicated the forest type burned at a given severity in proportion to its availability, $w_{i j}>1$ indicated the forest type burned at a given severity greater than expected by chance, and $w_{i j}<1$ indicated the forest type burned at a given severity less than expected.

We calculated the mean $\mathrm{B} / \mathrm{A}$ ratios and $95 \%$ confidence intervals $(\mathrm{CI})$ for all 472 wildfires rangewide and within areas of the three fire regimes (low severity, very frequent; mixed severity, frequent; high severity, infrequent). We used the amount of overlap in CIs to evaluate differences in $\mathrm{B} / \mathrm{A}$ ratios for fire severity and forest type combinations. For example, if $\mathrm{CI}$ for a $\mathrm{B} / \mathrm{A}$ ratio did not overlap 1 , we considered the area in each forest type to have burned at a given severity more or less than expected by chance. Due to non-normal distribution of $\mathrm{B} / \mathrm{A}$ ratios, we also conducted a Tukey post hoc comparison of contrasts between fire severity and forest types.

\section{Fire severity patterns and trends}

For each of the three forest types, we calculated the annual proportion of area burned at each of the three fire severities. We used linear regression to analyze longterm trends in yearly proportion of each forest type burning at high-severity fire. We considered slope estimates with CIs not overlapping 0 to indicate strong evidence of a trend in average percent of high-severity fire.

We examined normalized burned area frequency distribution patterns of observed fire severity based on RdNBR by forest type using kurtosis and skew statistics for the four wildfire seasons with the most area burned during our observation period: 1987, 2002, 2008, and 2017. We interpreted skewness values of $>1.0$ or $<-1.0$ to indicate a substantially skewed distribution in RdNBR by forest type. Increasing positive skewness indicated greater frequency of a forest type burning at lower severity classes, while negative skewness indicated greater frequency of burning in higher severity classes. Higher kurtosis values in RdNBR indicated narrow distribution with a given severity and lower kurtosis suggested more flat distribution over fire severities (Thode et al. 2011; Sugihara et al. 2018).

\section{Results}

Across all fire regimes NON-NESTING forests were consistently younger, more open, less structurally complex and had fewer large trees compared to INTERIOR and EDGE forests (Table 1). EDGE forests were consistent with northern spotted owl nesting conditions and generally had similar forest structure as INTERIOR forest albeit were on average younger and had greater 
variability in forest structure metrics by fire regime (Table 1).

\section{Burned/area ratios}

When combining all wildfires rangewide throughout the study, we found that INTERIOR forest had higher average odds of burning at unburned-low severity $(\mathrm{B} / \mathrm{A}=$ $1.17, \mathrm{CI}=1.13-1.22)$ and lower average odds of burning at moderate $(\mathrm{B} / \mathrm{A}=0.84, \mathrm{CI}=0.79-0.90)$ or high $(\mathrm{B} / \mathrm{A}=$ $0.89,95 \% \mathrm{CI}=0.81-0.96$ ) fire severity (Fig. 4a). Conversely, NON-NESTING forest had lower average odds of burning at unburned-low severity $(\mathrm{B} / \mathrm{A}=0.97, \mathrm{CI}=$ 0.95-0.98) and higher average odds of burning at moderate $(\mathrm{B} / \mathrm{A}=1.04, \mathrm{CI}=1.03-1.06)$ or high $(\mathrm{B} / \mathrm{A}=1.05$, $\mathrm{CI}=1.02-1.07$ ) fire severity (Fig. $4 \mathrm{a}$ ). The average $\mathrm{B} / \mathrm{A}$ ratios for EDGE forest was near 1.0 with CI overlapping 1 for each fire severity class (Fig. 4a). The Tukey post hoc comparison of $\mathrm{B} / \mathrm{A}$ ratios among the forest types revealed similar results as the assessment of CIs overlapping 1 (Additional file 2: Appendix 2).

Of the 472 fires, 307 fires had all or a portion of the perimeter $(1,110,031$ ha total area) in the low severity, very frequent fire regime area, 309 fires $(1,027,364$ ha) were in the mixed severity, frequent regime, and 114 fires $(309,205$ ha) were in the high severity, infrequent fire regime. In the low severity, very frequent regime, INTERIOR forest had higher odds of burning at low severity $(\mathrm{B} / \mathrm{A}=1.25, \mathrm{CI}=1.18-1.31)$ and lower odds of burning at moderate $(\mathrm{B} / \mathrm{A}=0.81, \mathrm{CI}=0.72-0.89)$ or high severity $(B / A=0.86, C I=0.74-0.99$; Fig. $4 \mathrm{~b})$. EDGE forest had lower odds of burning at moderate severity $(\mathrm{B} / \mathrm{A}=0.95, \mathrm{CI}=0.92-0.98)$, but $\mathrm{B} / \mathrm{A}$ ratios were near 1 for unburned-low $(\mathrm{B} / \mathrm{A}=1.02, \mathrm{CI}=0.99-1.05)$ and high severity $(\mathrm{B} / \mathrm{A}=1.04, \mathrm{CI}=0.94-1.13$; Fig. $4 \mathrm{~b})$. The NON-NESTING forest had low odds of burning at unburned-low severity $(\mathrm{B} / \mathrm{A}=0.95, \mathrm{CI}=0.93-0.96)$ but was more likely to burn at moderate $(\mathrm{B} / \mathrm{A}=1.06, \mathrm{CI}=$

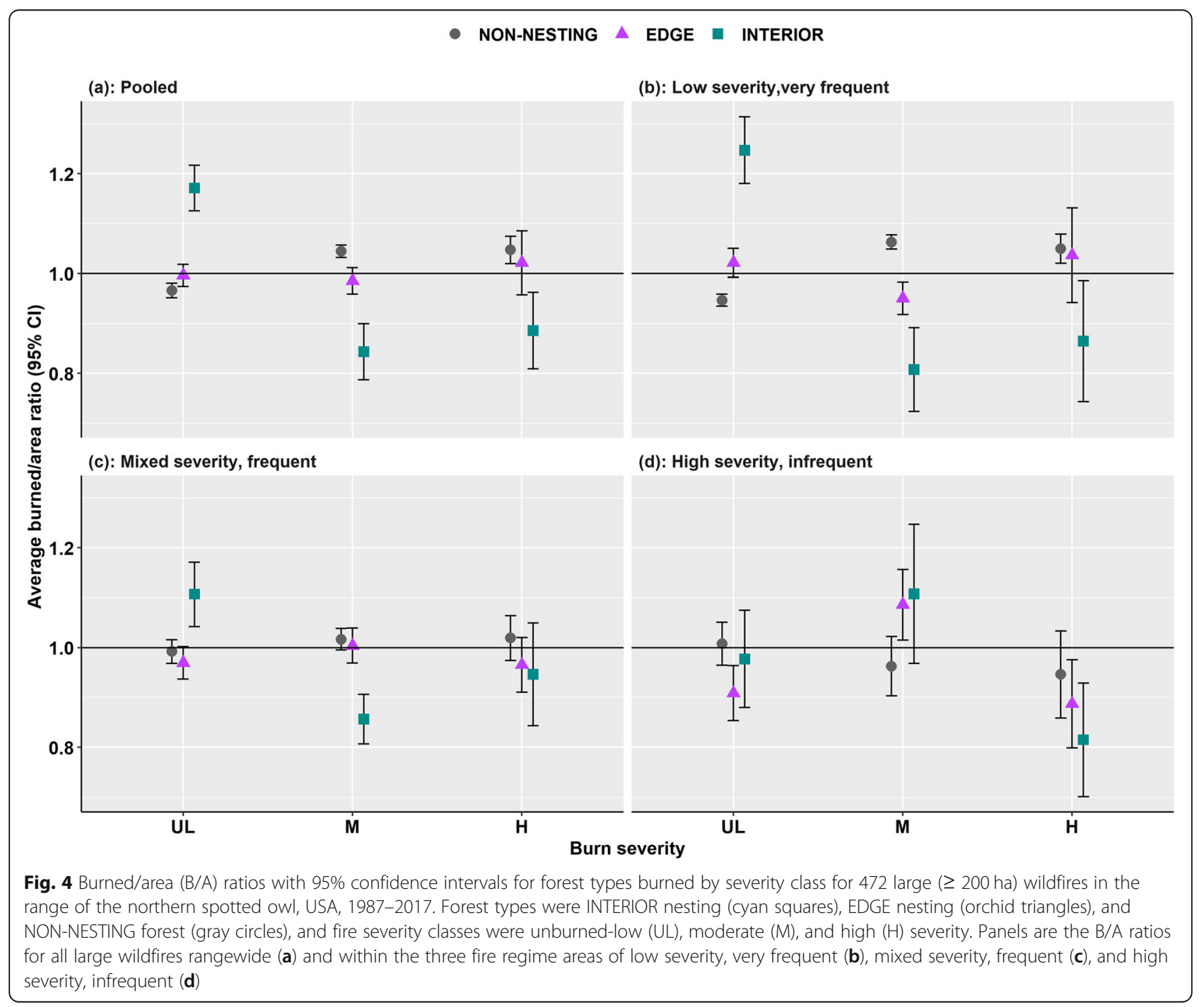


$1.05-1.08)$ or high severity $(\mathrm{B} / \mathrm{A}=1.05, \mathrm{CI}=1.02-1.08$; Fig. 4b).

Within the mixed severity, frequent regime, INTERIOR forest had higher odds of burning at unburned-low severity $(\mathrm{B} / \mathrm{A}=1.11, \mathrm{CI}=1.04-1.17)$ but less than expected in the moderate severity $(\mathrm{B} / \mathrm{A}=0.86, \mathrm{CI}=0.81-$ 0.91). The $\mathrm{B} / \mathrm{A}$ ratio for INTERIOR forest burning at high severity was $<1$, but $\mathrm{CI}$ overlapped 1 ( $\mathrm{CI}=0.84-$ 1.05; Fig. 4c). EDGE and NON-NESTING forest types had B/A ratios near 1.0 and $\mathrm{CI}$ overlapping 1.0 for each fire severity (Fig. 4c).

For fires in the high severity, infrequent fire regime, INTERIOR forests burned at high severity less than expected $(\mathrm{B} / \mathrm{A}=0.82, \mathrm{CI}=0.70-0.93)$, but CIs overlapped 1.0 at the two lower fire severities (Fig. 4d). The EDGE forest had low odds of burning at high severity $(\mathrm{B} / \mathrm{A}=$ $0.89, \mathrm{CI}=0.80-0.98)$ and unburned-low severity $(\mathrm{B} / \mathrm{A}=$ $0.91, \mathrm{CI}=0.85-0.96)$, but high odds of burning at moderate severity $(\mathrm{B} / \mathrm{A}=1.09, \mathrm{CI}=1.02-1.16)$. The CIs for the NON-NESTING forest overlapped 1.0 for all three severity classes. A Tukey post hoc comparison of B/A ratios among severity classes and forest types indicated that INTERIOR forest tended to burn at unburned-low severity compared to EDGE and NON-NESTING forests (Additional file 2: Appendix 2).

\section{Fire severity patterns and trends}

The number of fires and area burned varied greatly among years studied, with higher number of fires corresponding with more area burned (Fig. 3). Exceptions to this were the years 2002 and 2017, where two large fires
(2002 Biscuit Complex = 200,444 ha; 2017 Chetco Bar = $77,103 \mathrm{ha}$ ) accounted for most of the area burned.

The proportion of area burned each year differed among years for all forest types (Fig. 5). For most years, the proportion of area burned at high severity was less than area burned at moderate or unburned-low severity (Fig. 5). All forest types had some evidence of increasing linear trends in the average yearly percent of area burned at high severity (Fig. 5), but only in the NONNESTING forest was there strong evidence of an increase (Fig. 5d). The slope estimates for NONNESTING forest indicated a $0.7 \%(\mathrm{CI}=0.29-1.05 \%)$ annual increase in average area burned at high severity.

For each of the four largest wildfire seasons, each burning over 200000 ha of potential nesting forests, the fire severity frequency distribution patterns differed between forest types (Fig. 6). Frequency distributions for INTERIOR were consistently most positively skewed (2.3-3.3) and had the greatest kurtosis (5.0-10.9) toward low severity, with most of the area burning at lower severities (Fig. 6). Although less pronounced than for INTERIOR, EDGE forest was positively skewed (1.1-2.6) and had greater kurtosis (1.1-2.6), exhibiting a low to moderate severity pattern (Fig. 6). Skew and kurtosis for EDGE was intermediate to INTERIOR and NON-NESTING. For NON-NESTING forest, skewness was moderately positive $(0.8-1.4)$ and little kurtosis $(-1.2-0.6)$, indicating a relative even distribution across the RdNBR spectrum (Fig. 6). Fire severity frequency distributions were the most bimodal during the 2002 and 2017 fire seasons (Fig. 6). These were the years with two largest wildfires during our
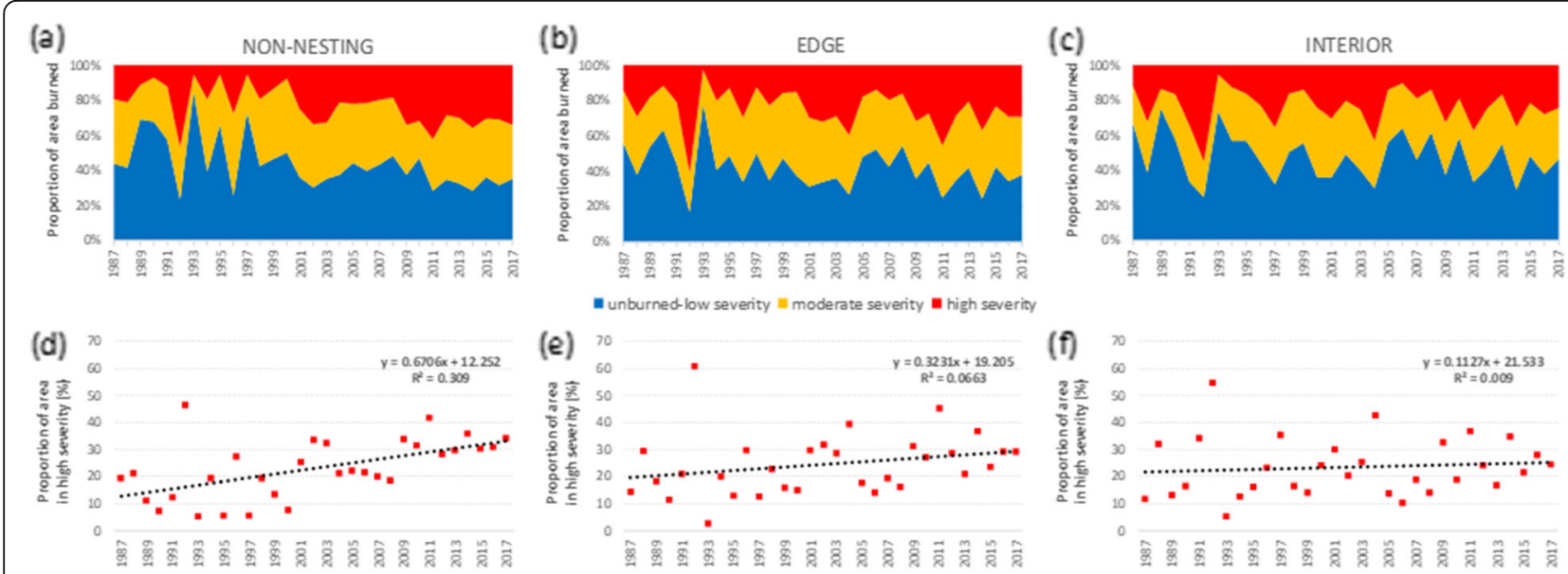

Fig. 5 Proportion of annual area of potential nesting forest burned at three fire severities [unburned-low (UL), moderate (M), and high (H)] in three forest types [NON-NESTING (a), EDGE (b), and INTERIOR (c)]. Also are the linear trends in annual proportion of fires burning at high severity in NON-NESTING (d), EDGE (e), and INTERIOR (f) forest types. Data are from 472 large ( $\geq 200$ ha) wildfires occurring throughout the range of the northern spotted owl, USA, 1987-2017. Potential nesting forests were those areas with environmental conditions of elevation (below 2000 m) and soil types that without disturbance could develop into suitable forest for nesting and roosting by spotted owls given time for succession 


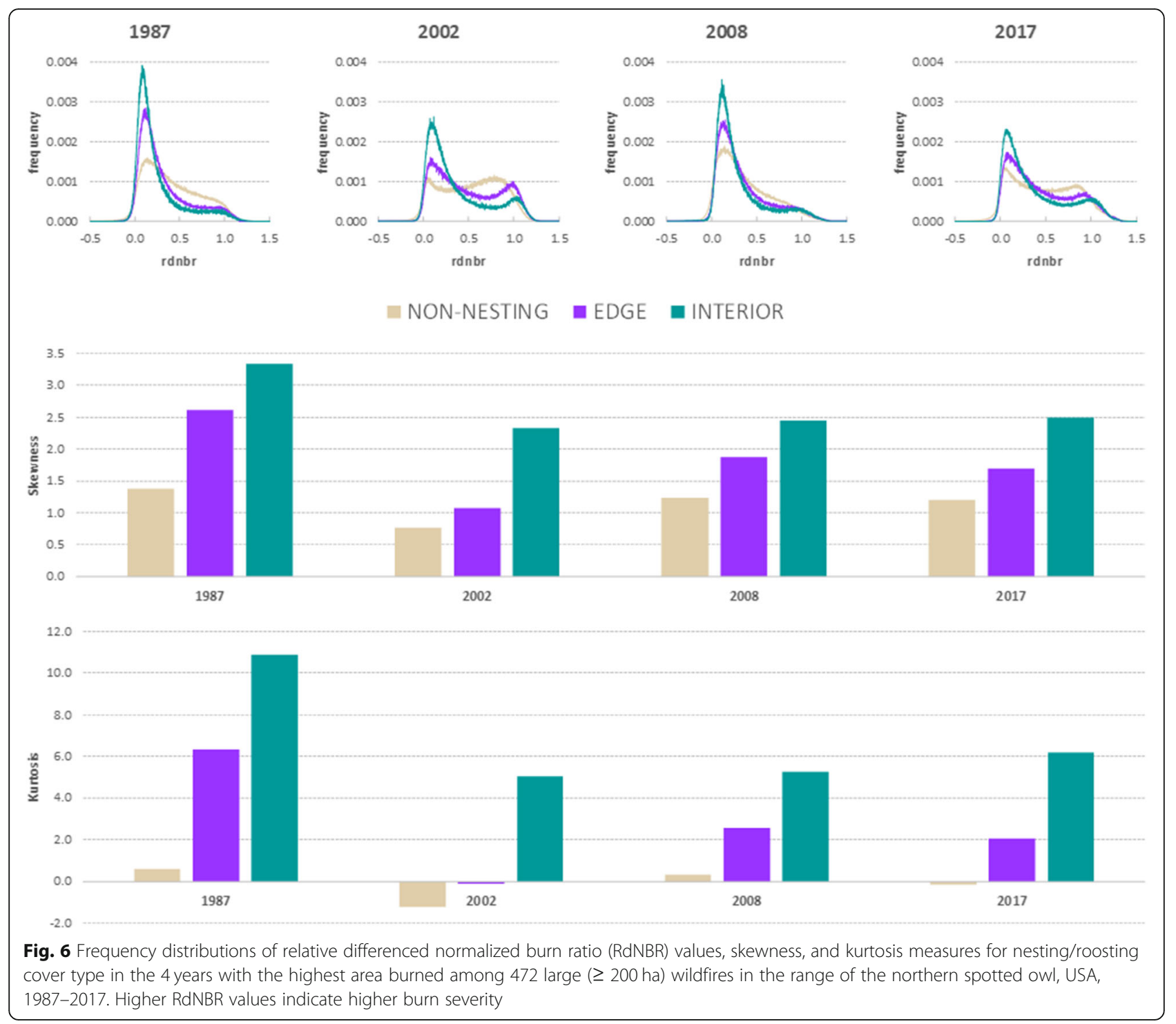

study period (2002 Biscuit Complex and 2017 Chetco Bar Fire) and had the highest area burned per wildfire (Fig. 3).

\section{Discussion}

Here, we analyzed the likelihood of different forest types burning at three fire severities during 472 large wildfires that occurred over a span of 30 years throughout the range of northern spotted owls in the Pacific Northwest, USA. The spatial and temporal expanse of our dataset and the ability to generate annual maps of northern spotted owl nesting forest afforded us the ability to gain unprecedented insights into the function of suitable nesting forest as fire refugia. Strong evidence indicates that large wildfires are a severe threat to northern spotted owl habitat and populations (Clark et al. 2011; Davis et al. 2011; Clark et al. 2013; Rockweit et al. 2017; Lesmeister et al. 2019), yet the issue has been debated in the scientific literature, especially when also considering other spotted owl subspecies (e.g., Hanson et al. 2009; Spies et al. 2010; Ganey et al. 2017; Lesmeister et al. 2018). In some cases, published literature contains errors and bias, which was highlighted recently by Jones et al. (2020a). The primary natural fire regimes and fire severity patterns differ between northern spotted owls and the other spotted owl subspecies (California and Mexican spotted owls); therefore, caution should be used in assuming that our findings on northern spotted owls are applicable to forests used by those other subspecies. We also posit that population response and burn severity patterns within the range of the other subspecies are likely different than what should be expected for northern spotted owls and their habitat.

In addition to wildfire, multiple other stressors, especially barred owls, play a role in degrading the prognosis 
for persistence of northern spotted owl populations (Lesmeister et al. 2018; Miller et al. 2018; Wiens et al. 2019; Franklin et al. 2021; Jenkins et al. 2021). We approached this study to better understand the long-term and broadscale patterns of risk that large wildfires (especially highseverity fire) pose to northern spotted owls and their habitat because the extent and frequency of wildfires is expected to increase with climate change (McKenzie et al. 2004; Davis et al. 2017; Halofsky et al. 2020). We observed consistent patterns of fire severity in different forest types used by this old forest obligate and found that suitable nesting forest played an important role as fire refugia in the face of increasing wildfire activity.

Our findings from broadscale and long-term data were similar to those from Douglas Complex wildfires that burned in a mixed-ownership landscape of the KlamathSiskiyou ecoregion of southwestern Oregon, USA (Zald and Dunn 2018; Lesmeister et al. 2019). The Douglas Complex burned an area of 38,000 ha in mixed-severity with large patches of high-severity fire. Older forests in late-successional reserves (i.e., suitable nesting forest) burned at lower severity despite having higher fuel loading than other forest types within the fire perimeters (Lesmeister et al. 2019). Ownership patterns were also a strong predictor of fire severity for the Douglas Complex, where federally managed lands were primarily comprised of late-successional forest reserves that burned at lower severity compared to plantation forests with homogenous fuel loads on private timber industry lands (Zald and Dunn 2018). Those studies suggested that, in addition to the contribution to northern spotted owl conservation, older forests functioned as fire refugia and had an added benefit of buffering the effects of climate change-induced increases in wildfire occurrence.

In our study, interior nesting forest tended to burn at lower severity compared to other forest types, especially when compared to the non-nesting forest type that was primarily younger or open-canopied forest (Table 1). Edges and fragmented nesting forest burned at intermediate severities, with edges presumably buffering interior forest from higher fire severity in non-nesting forest. Contrary to our predictions, these patterns of burn severity were strongest in the low severity, very frequent regime and least evident in the high severity, infrequent fire regime. We expected to observe a largely flat distribution of fire severity across forest types in the low severity, very frequent regime because these are primarily dry forest types that tend to have lower moisture levels during the fire season and, owing to fire exclusion for the past century, have higher fuel loading and susceptibility to high-severity fire compared to historic levels (Agee 1993; Spies et al. 2018). In dry forest types of Oregon, tree densities are more than four times greater, average canopy cover has increased, and species composition has shifted from a century ago (Hagmann et al. 2014; Hagmann et al. 2017). In many dry forests, these altered conditions have been associated with increased fire severities (e.g., Bigio et al. 2010; Hagmann et al. 2019; Marlon 2020). Baker (2015) suggested that some northern spotted owl habitat was historically maintained as fire refugia within the dry forests (with historical frequent fire return interval) of the study area. Therefore, the patterns we observed may have been relatively natural dynamics of fire severity in those dry forests. Fire refugia persisting through multiple fires in these landscapes typically have topography, elevation, and slope that result in moister conditions that facilitate development of older, intact, and closed-canopy conifer forest (Downing et al. 2021). Additionally, fire refugia capacity is enhanced in forests that are left unmanaged post wildfire because they burn at lower severity than areas salvage-logged following wildfires (Thompson et al. 2007; Thompson and Spies 2010).

Several interacting factors may have caused the differences in the patterns we observed with northern spotted owl nesting forests tending to burn as lower severity. We hypothesize one of the important mechanisms potentially driving the fire severity patterns of lower severity fire in suitable nesting forest was the long-known relationship (see Hursh and Connaughton 1938; Countryman 1955) between differing microclimates of forests and susceptibility to high-severity wildfire. In the moist forests of the Pacific Northwest, closed-canopy, structurally complex late-successional conifer forests with high biomass (i.e., northern spotted owl nesting forest) maintain cooler, more temperate microclimates and provide an insulating effect on temperatures (Chen et al. 1995; Frey et al. 2016; Downing et al. 2021) and result in lower fire severity (Meigs et al. 2020). Our findings of fire severity patterns suggest these factors may also reduce fire severity of older forests in the mixed-and low-severity fire regimes of the study area. Fire behavior and severity is largely driven by interactions among wind, humidity, temperature, fuels, and topography (Countryman 1964; Thompson and Spies 2009; Halofsky et al. 2011). Some open-canopied forests and younger even-aged and densely stocked stands have hotter, drier, and windier microclimates, and those conditions decrease dramatically over relatively short distances into the interior of older forests with multi-layer canopies and high tree density (Chen et al. 1995; Heithecker and Halpern 2007; Arroyo-Rodríguez et al. 2016).

Our objectives were to quantify burn severity patterns specific to suitable nesting forest over many wildfires and years, thus we did not include effects like drought, topography, weather, multiple spatial scales, and previous fires that could have explained some of the variance in area burned by severity classes (Keyser and 
Westerling 2019; Meigs et al. 2020). For example, on the 2011 Wallowa Fire in the range of the Mexican spotted owl, the relationship between burn severity and pre-fire nesting forest suitability varied with spatial scale (Wan et al. 2020). A multi-scale evaluation of fire severity patterns warrants additional attention and could provide further insights into the interaction between northern spotted owl nesting forest and fire severity. An assumption in our B/A ratio analysis was that all forest types were equally available to burn at each severity, but other factors that affect wildfire severity could have also influenced the amount of forest types within fire perimeters. Lower severity wildfire tends to occur in areas with gentler topography (Skinner 1995; Heyerdahl et al. 2001; Alexander et al. 2006). If a particular forest type tends to be more prevalent in gentler topography, then reasoning suggests fire severity would tend to be lower in that forest type. In our study, the non-nesting forest typically occurred in gentler slopes compared to interior and edge forest types (Additional file 3: Appendix 3). Additionally, fire suppression efforts, including road access and tactical decisions for the location of fire lines and burnout activities, could affect fire spread and behavior on large wildfires. The effect of fire suppression activities on the fire severity patterns we observed is unknown but these activities are enhanced by road access that is more readily available on highly managed forest lands. As such, if fire suppression or slope affected burn severity patterns, they would likely function to decrease severity and extent on the non-nesting forest type. Further testing of hypotheses for independent and interacting drivers in fire severity patterns is needed.

We found an increasing trend in the proportion of annual area burned by high-severity fire over the duration of our study, but the trend occurred most strongly in the non-nesting forest type. These findings suggest that the effects of climate change on the occurrence of highseverity wildfires may be most pronounced in nonnesting forests and interior nesting forest appears to function as fire refugia buffering the trend of increasing wildfire activity. Forests functioning as fire refugia can support ecosystem resilience to disturbances as well as postfire ecosystem recovery and biodiversity (Meddens et al. 2018). Our findings are consistent with recent research that found a higher amount and quality of fire refugia in closed-canopy older forests compared to younger and more open-canopied forest cover types (Meigs and Krawchuk 2018; Andrus et al. 2021). In conifer forests of the Pacific Northwest, old-growth and latesuccessional forests have the highest likelihood of burning at low severities especially in landscapes with high topographic variability (Meigs et al. 2020; Downing et al. 2021), even during drought years with high-fire weather conditions (Lesmeister et al. 2019). Interior forests functioned as fire refugia during our observed timespan, but it remains unknown if they are ephemeral refugia or will function as persistent refugia with a changing climate and shorter fire return intervals. However, mature forests have higher resiliency to fire effects and climate variability, especially when not subject to fragmentation in a matrix of young flammable patches that can shift mature forests to an alternative steady state more prone to repeat high-severity fire (Thompson and Spies 2010; Kitzberger et al. 2012). Similarly, examining forests in Australia, Duff et al. (2018) showed that older forests had higher resilience to drought conditions that increased flammability of vegetation, thus functioned as fire refugia. Intact old forest with less fragmentation in Amazonian forests also function as refugia by ameliorating the effects of fire (Silva Junior et al. 2018; Silva et al. 2018; Maillard et al. 2020).

In the years with extremely large wildfires (2002 and 2017), there was a bimodal distribution in fire severity in all forest types, potentially degrading the function of suitable nesting forest as fire refugia. The 2002 fire season was dominated by the Biscuit Fire, which at over 200,000 ha was the largest fire in our study. The 2017 fire season had the greatest amount of area burned of the years we sampled and was dominated by the Chetco Bar Fire which burned over 190,000 ha. The bimodal patterns we observed in these 2 years were consistent with theorized fire severity distributions when extremely large fires (i.e., megafires), that occur very infrequently, produce large patches of high-severity burns (van Wagtendonk and Fites-Kaufman 2006). Strong dry foehn winds were the primary factor driving the extent and severity of the 2002 and 2017 megafires with katabatic heating that carried westward from high-density air from higher elevations in the deserts east of the Cascade Mountains (Ustin et al. 2009; Halofsky et al. 2011). Extreme wind events occurring episodically are also primary predictors of spatial variation in large wildfires in other regions (e.g., Moritz et al. 2010). These rare and extreme weather conditions have been the primary driver of the most well-known megafires during recorded history of the region, including the 1902 Yacolt burn, 1933 Tillamook burn, and 1936 Bandon fire, (Dague 1930; Dague 1934; Martin et al. 1974; Herring and Greene 2001; Zyback 2004; Potter 2012). One or a few very infrequent, wind-driven crown fires can shift severity distributions to more and larger high-severity patches, creating a bimodal distribution and increasing loss of old forest (Thode et al. 2011; Cansler and McKenzie 2014). If the occurrence of these extreme weather events increases with climate change then suitable nesting forest and northern spotted owl populations will be further threatened. Early evidence from recent megafires occurring in the most extreme years suggests 
there may be a further shift to a more equal distribution of fire severities. In September 2020, five megafires in Oregon burned about 329,000 ha in relatively equal distribution of severity (low $=31 \%$, moderate $=28 \%$, high $=$ $42 \%$ ) during a sustained and historic windstorm that caused the record-setting fire season (Antczak et al. 2020; Higuera and Abatzoglou 2020, R. J. Davis unpublished data; Mass 2020). In these megafires, extreme easterly foehn winds resulted in extraordinary fire growth in all forest types regardless of management history. During extreme fire weather events, the relative importance of fuels influencing burn severity diminishes because the effects of weather (fuel moisture, temperature, and wind speed) primarily determine fire intensity and crown fire development (Bessie and Johnson 1995).

Timber harvest remains one of the primary threats to suitable nesting forests used by northern spotted owls (Lesmeister et al. 2018), but on federal lands managed under the Northwest Forest Plan, the threat from wildfire is now greater than the threat from timber harvest (Davis et al. 2016). These are concerning trends, especially considering that the extent and frequency of large wildfires is expected to increase with climate change (Davis et al. 2017; Wan et al. 2019). Forest management plans-even some with stated goals to enhance northern spotted owl conservation-may seek to reduce wildfire risk by thinning forest stands of all ages using practices that modify forest structure by increasing canopy base height, reducing crown contiguity and bulk density, and reducing forest fuels. These actions can degrade the suitability of the forest for nesting by northern spotted owls and may decrease wildfire severity in the short term (Agee and Skinner 2005; Martinson and Omi 2013; Kalies and Yocom Kent 2016; Prichard et al. 2020). However, these actions are less effective at reducing wildfire extent and severity on a large scale beyond a short time window, so need to be repeatedly managed to maintain effectiveness (Stone et al. 2003; Reinhardt et al. 2008; Barnett et al. 2016; Schoennagel et al. 2017).

Converting older, closed-canopy forests that function as fire refugia to more open, managed forests does not assure a dampening effect on wildfire severity, due in part to the complex changes in the microclimate of forest stands after thinning. Recently disturbed forests have higher and more variable shortwave radiation, temperature, and windspeed (Chen et al. 1999), all of which can increase fire severity (Estes et al. 2017). Fuel loads and arrangement are a component of the fire environment, so forest thinning that alters microclimates may increase flammability if fuel loading is not repeatedly maintained. Variable retention harvesting, which aims to mimic natural forest disturbance regimes and retains old forest structures, including snags and logs, is becoming more commonplace (Franklin and Donato 2020). These silvicultural prescriptions may retain enough forest structure to function as edge nesting forest and thus be less prone to high-severity fire than nonnesting forest. These actions may be especially effective if the resulting landscape has extensive areas of interior nesting forest. Additional research is needed to predict the conditions under which northern spotted owl nesting forest is likely to remain fire refugia in the face of increasing fire activity with climate change.

\section{Conclusions}

We present evidence that suitable nesting forests for northern spotted owls tend to burn at lower severity than the surrounding landscape and thus may be more resilient to increasing trends of wildfire. We do not infer that our results trivialize the threat to northern spotted owls from large wildfires because high-severity fires result in the loss of suitable nesting forest and lower survival (Rockweit et al. 2017; Lesmeister et al. 2019). Particularly in the face of barred owl competition, loss of suitable nesting forest is concerning because widespread old-growth forest helps to dampen northern spotted owl territory extinction rates, improves colonization and survival rates, facilitates resource partitioning, and decreases breeding dispersal distance and rates (Jenkins et al. 2019a; Jenkins et al. 2019b; Franklin et al. 2021; Jenkins et al. 2021). Therefore, barred owl management coupled with conservation of suitable nesting forest and restoration efforts to promote forest resilience to climate change are likely necessary for successful recovery of northern spotted owl populations and other biodiversity goals of the NWFP (Lesmeister et al. 2018; Spies et al. 2019; Yackulic et al. 2019; Wiens et al. 2021). Wildfires that remove large swaths of suitable nesting forest are of particular concern because it may take over a century for forest structure to recover and become suitable for nesting by northern spotted owls. Jones et al. (2016) found clear evidence for detrimental impact of a megafire on a California spotted owl population, and other research showed landscape use decreasing with larger patches of high-severity fire (Jones et al. 2020b; Kramer et al. 2021). Although high-severity fires have been an important ecological process in Pacific Northwest forests for at least 11,000 years with frequent fires steadily increasing over the past 4000 years (Walsh et al. 2015), periodic megafires that result in extremely large losses of nesting forest pose a conservation concern for northern spotted owls. The historic landscape with millions of hectares of intact old-growth forest could incur these occasional events and maintain function, but the contemporary amount and spatial extent of suitable nesting forest is a small percentage of what existed historically 
and primarily confined to federal lands making the landscape less resilient to megafires.

Under most fire weather, suitable nesting forests burn at lower severity compared to the surrounding landscape but are at increased risk of burning at high-severity when fragmented and surrounded by non-nesting forests (primarily younger forests) which are most susceptible to loss due to wildfire. These findings support the recovery actions in the 2011 northern spotted owl Recovery Plan that call for conservation of existing high-quality northern spotted owl nesting forest and, outside those areas, focused treatments to increase the extent of forest types with large diameter trees, high amounts of canopy cover, and decadence components such as brokentopped live trees, mistletoe, cavities, large snags, and fallen trees (USFWS 2011). By identifying the potential role that intact old-growth and late-successional forests may play to enhance fire resiliency in the face of climate change, this study highlights the potential benefits of adaptive management and landscape-scale restoration.

\section{Supplementary Information}

The online version contains supplementary material available at https://doi. org/10.1186/s42408-021-00118-z.

\section{Additional file 1: Appendix 1. Example of wildfire perimeters} juxtaposed against our owl nesting/roosting cover type model (Map A) and burn severity from Landscape Change Monitoring System (Map B) for the Douglas complex fires which burned 20479 ha in Oregon, USA, in 2013.

Additional file 2: Appendix 2. Tukey post hoc comparison of burned/ area $(B / A)$ ratios of severity $(U L, M, H)$-forest type (INTERIOR, EDGE, NONNESTING) combinations for 472 large ( $\geq 200 \mathrm{ha}$ ) fires within the range of the Northern Spotted Owl, 1987-2017. Fire severity codes are UL= unburned-low, $\mathrm{M}=$ moderate severity, $\mathrm{H}=$ high severity.

Additional file 3: Appendix 3. Figures of the frequency distribution of slope (30 m pixels) within each forest cover type for the large wildfire years of 1987 (a) and 2017 (b). The NON-NESTING forests had high distribution and occurred on gentler slopes compared to EDGE and INTERIOR forest types.

\section{Acknowledgements}

We thank three reviewers for helpful comments on a previous draft that improved the manuscript. The findings and conclusions in this publication are those of the authors and should not be construed to represent any official US Department of Agriculture or US Government determination or policy. The use of trade or firm names in this publication is for reader information and does not imply endorsement by the US Government of any product or service.

\section{Authors' contributions}

DBL developed the analysis concept, secured funding, interpreted statistics, and did the majority of manuscript writing; RJD developed the analysis concept, compiled data, created figures, and contributed to manuscript writing; SGS performed GIS analysis, compiled and analyzed data, and contributed to manuscript writing; ZY developed the original spatial datasets, assisted in interpreting statistics, and contributed to writing the manuscript. The authors read and approved the final manuscript.

\section{Funding}

Funding for this project was provided by USDA Forest Service, Pacific Northwest Research Station, Portland, OR, USA.
Availability of data and materials

If this paper is accepted, we will make the code and datasets used in our analyses available in a public repository.

\section{Declarations}

Ethics approval and consent to participate

Not applicable.

\section{Consent for publication}

Not applicable.

\section{Competing interests}

The authors declare that they have no competing interests.

\section{Author details}

'USDA Forest Service, Pacific Northwest Research Station, 3200 NW Jefferson Way, Corvallis, OR 97331, USA. ${ }^{2}$ Department of Fisheries, Wildlife, and Conservation Sciences, Oregon State University, Corvallis, OR 97331, USA. ${ }^{3}$ USDA Forest Service, Pacific Northwest Region, 3200 NW Jefferson Way, Corvallis, OR 97331, USA. ${ }^{4}$ USDA Forest Service, Rocky Mountain Research Station, 507 25th Street, Ogden, UT 84401, USA.

Received: 26 February 2021 Accepted: 25 August 2021

Published online: 05 November 2021

\section{References}

Abatzoglou, J.T., and A.P. Williams. 2016. Impact of anthropogenic climate change on wildfire across western US forests. Proceedings of the National Academy of Sciences U S A 113 (42): 11770-11775. https://doi.org/10.1073/ pnas.1607171113.

Agee, J.K. 1993. Fire Ecology of Pacific Northwest Forests. Washington, DC: Island Press.

Agee, J.K., and C.N. Skinner. 2005. Basic principles of forest fuel reduction treatments. Forest Ecology and Management 211 (1-2): 83-96. https://doi. org/10.1016/j.foreco.2005.01.034.

Alexander, J.D., N.E. Seavy, C.J. Ralph, and B. Hogoboom. 2006. Vegetation and topographical correlates of fire severity from two fires in the KlamathSiskiyou region of Oregon and California. International Journal of Wildland Fire 15 (2): 237-245. https://doi.org/10.1071/WF05053.

Andrus, R.A., A.J. Martinez, G.M. Jones, and A.J.H. Meddens. 2021. Assessing the quality of fire refugia for wildlife habitat. Forest Ecology and Management 482: 118868. https://doi.org/10.1016/j.foreco.2020.118868.

Antczak, J., S. Cline, and G. Flaccus. 2020. Lightning storm, easterly wind: How the wildfires got so bad. The Associated Press https://headtopics.com/us/ lightning-storm-easterly-wind-how-the-wildfires-got-so-bad-15714441. Accessed 1 Oct 2020.

Arroyo-Rodríguez, V., R.A. Saldaña-Vázquez, L. Fahrig, and B.A. Santos. 2016. Does forest fragmentation cause an increase in forest temperature? Ecological Research 32 (1): 81-88. https://doi.org/10.1007/s11284-016-1411-6.

Baker, W.L. 2015. Historical northern spotted owl habitat and old-growth dry forests maintained by mixed-severity wildfires. Landscape Ecology 30 (4): 655666. https://doi.org/10.1007/s10980-014-0144-6.

Barnett, K., S. Parks, C. Miller, and H. Naughton. 2016. Beyond fuel treatment effectiveness: characterizing interactions between fire and treatments in the US. Forests 7 (12): 237. https://doi.org/10.3390/f7100237.

Bell, D.M., S.A. Acker, M.J. Gregory, R.J. Davis, and B.A. Garcia. 2021. Quantifying regional trends in large live tree and snag availability in support of forest management. Forest Ecology and Management 479: 118554. https://doi.org/1 0.1016/j.foreco.2020.118554

Bessie, W.C., and E.A. Johnson. 1995. The relative importance of fuels and weather on fire behavior in subalpine forests. Ecology 76 (3): 747-762. https://doi.org/10.2307/1939341.

Bigio, E., T.W. Swetnam, and C.H. Baisan. 2010. A comparison and integration of tree-ring and alluvial records of fire history at the Missionary Ridge Fire, Durango, Colorado, USA. The Holocene 20 (7): 1047-1061. https://doi.org/1 $0.1177 / 0959683610369502$.

Bradley, C.M., C.T. Hanson, and D.A. DellaSala. 2016. Does increased forest protection correspond to higher fire severity in frequent-fire forests of the western United States? Ecosphere 7 (10): e01492. 
Cansler, C.A., and D. McKenzie. 2014. Climate, fire size, and biophysical setting control fire severity and spatial pattern in the northern Cascade Range, USA. Ecological Applications 24 (5): 1037-1056. https://doi.org/10.1890/13-1077.1.

Chen, J., J.F. Franklin, and T.A. Spies. 1995. Growing-season microclimate gradients from clearcut edges into old-growth Douglas-fir forests. Ecological Applications 5 (1): 74-86. https://doi.org/10.2307/1942053.

Chen, J., S.C. Saunders, T.R. Crow, R.J. Naiman, K.D. Brosofske, G.D. Mroz, B.L. Brookshire, and J.F. Franklin. 1999. Microclimate in forest ecosystem and landscape ecology: Variations in local climate can be used to monitor and compare the effects of different management regimes. BioScience 49 (4): 288-297. https://doi.org/10.2307/1313612.

Clark, D.A., R.G. Anthony, and L.S. Andrews. 2011. Survival rates of northern spotted owls in post-fire landscapes of southwest Oregon. Journal of Raptor Research 45 (1): 38-47. https://doi.org/10.3356/JRR-10-42.1.

Clark, D.A., R.G. Anthony, and L.S. Andrews. 2013. Relationship between wildfire, salvage logging, and occupancy of nesting territories by northern spotted owls. The Journal of Wildlife Management 77 (4): 672-688. https://doi.org/10.1 002/jwmg.523.

Coates, P.S., M.A. Ricca, B.G. Prochazka, K.E. Doherty, M.L. Brooks, and M.L. Casazza. 2015. Long-term effects of wildfire on greater sage-grouse-Integrating population and ecosystem concepts for management in the Great Basin. U.S. Geological Survey Open-File Report 2015: 1165. https://doi.org/10.3133/ofr201 51165 .

Cohen, W.B., Z. Yang, S.P. Healey, R.E. Kennedy, and N. Gorelick. 2018. A LandTrendr multispectral ensemble for forest disturbance detection. Remote Sensing of Environment 205: 131-140. https://doi.org/10.1016/j.rse.2017.11.015.

Cohen, W.B., Z. Yang, and R. Kennedy. 2010. Detecting trends in forest disturbance and recovery using yearly Landsat time series: 2. TimeSync Tools for calibration and validation. Remote Sensing of Environment 114 (12): 2911-2924. https://doi.org/10.1016/j.rse.2010.07.010.

Comfort, E.J., D.A. Clark, R.G. Anthony, J. Bailey, and M.G. Betts. 2016. Quantifying edges as gradients at multiple scales improves habitat selection models for northern spotted owl. Landscape Ecology 31 (6): 1227-1240. https://doi.org/1 0.1007/s10980-015-0330-1.

Countryman, C.M. 1955. Old-growth conversion also converts fire climate. USDA Forest Service Fire Control Notes 17: 15-19.

Countryman, C.M. 1964. Mass fires and fire behavior. Research Paper PSW-19. Berkeley: USDA Forest Service.

Dague, C.I. 1930. Disastrous fire weather of september, 1929. Monthly Weather Review 58 (9): 368-370. https://doi.org/10.1175/1520-0493(1930)58<368: DFWOS $>2.0 . \mathrm{CO} ; 2$

Dague, C.I. 1934. The weather of the Great Tillamook, Oreg., Fire of August 1933. Monthly Weather Review 62 (7): 227-231. https://doi.org/10.1175/1520-0493 (1934)62<227:TWOTGT>2.0.CO:2

Davis, R., Z. Yang, A. Yost, C. Belongie, and W. Cohen. 2017. The normal fire environment-Modeling environmental suitability for large forest wildfires using past, present, and future climate normals. Forest Ecology and Management 390: 173-186. https://doi.org/10.1016/j.foreco.2017.01.027.

Davis, R.J., K.M. Dugger, S. Mohoric, L. Evers, and W.C. Aney. 2011. Northwest Forest Plan-the First 15 Years (1994-2008): Status and Trends of Northern Spotted OWl Populations and Habitat vol PNW-GTR-850. Portland: USDA Forest Service, Pacific Northwest Research Station.

Davis, R.J., B. Hollen, J. Hobson, J.E. Gower, and D. Keenum. 2016. Northwest Forest Plan-the First 20 years (1994-2013): Status and Trends of Northern Spotted Owl Habitats vol PNW-GTR-929. Portland: USDA Forest Service, Pacific Northwest Research Station.

Davis, R.J., D.B. Lesmeister, Z. Yang, B. Hollen, B. Tuerler, J. Hobson, J. Guetterman, and A. Stratton. In Press. Northwest forest plan-the first 25 years (1994-2017): Status and trends of northern spotted owl habitats. General Technical Report PNW-GTR-XXX. Portland: USDA Forest Service, Pacific Northwest Research Station.

Davis, R.J., and J. Lint. 2005. Habitat status and trends. In: Lint J (ed) Status and Trends of Northern Spotted OWl Populations and Habitat, vol PNW-GTR-648. PNW-GTR-648, 21-82. Portland: USDA Forest Service, Pacific Northwest Research Station.

Downing, W.M., G.W. Meigs, M.J. Gregory, and M.A. Krawchuk. 2021. Where and why do conifer forests persist in refugia through multiple fire events? Global Change Biology early online: 27 (15): 3642-3656. https://doi.org/10.1111/gcb.1 5655.

Duff, T.J., J.G. Cawson, and S. Harris. 2018. Dryness thresholds for fire occurrence vary by forest type along an aridity gradient: evidence from Southern
Australia. Landscape Ecology 33 (8): 1369-1383. https://doi.org/10.1007/s1 0980-018-0655-7.

Dugger, K.M., E.D. Forsman, A.B. Franklin, R.J. Davis, G.C. White, C.J. Schwarz, K.P. Burnham, J.D. Nichols, J.E. Hines, C.B. Yackulic, P.F. Doherty Jr., L.L. Bailey, D.A Clark, S.H. Ackers, L.S. Andrews, B. Augustine, B.L. Biswell, J.A. Blakesley, P.C. Carlson, M.J. Clement, L.V. Diller, E.M. Glenn, A. Green, S.A. Gremel, D.R. Herter, J.M. Higley, J. Hobson, R.B. Horn, K.P. Huyvaert, C. McCafferty, T.L. McDonald, K. McDonnell, G.S. Olson, J.A. Reid, J. Rockweit, V. Ruiz, J. Saenz, and S.G. Sovern. 2016. The effects of habitat, climate and Barred Owls on the longterm population demographics of Northern Spotted Owls. Condor 118 (1): 57-116. https://doi.org/10.1650/CONDOR-15-24.1.

Estes, B.L., E.E. Knapp, C.N. Skinner, J.D. Miller, and H.K. Preisler. 2017. Factors influencing fire severity under moderate burning conditions in the Klamath Mountains, northern California, USA. Ecosphere 8 (5): e01794. https://doi.org/1 $0.1002 /$ ecs 2.1794

Fielding, A.H., and J.F. Bell. 1997. A review of methods for the assessment of prediction errors in conservation presence/absence models. Environmental Conservation 24 (1): 38-49. https://doi.org/10.1017/S0376892997000088.

Fontaine, J.B., and P.L. Kennedy. 2012. Meta-analysis of avian and small-mammal response to fire severity and fire surrogate treatments in U.S. fire-prone forests. Ecological Applications 22 (5): 1547-1561. https://doi.org/10.1890/120009.1

Forsman, E.D., E.C. Meslow, and H.M. Wight. 1984. Distribution and biology of the spotted owl in Oregon. Wildlife Monographs 48 (2): 1-64.

Foster, L.J., K.M. Dugger, C.A. Hagen, and D.A. Budeau. 2019. Greater sage-grouse vital rates after wildfire. The Journal of Wildlife Management 83 (1): 121-134. https://doi.org/10.1002/jwmg.21573.

Franklin, A.B., K.M. Dugger, D.B. Lesmeister, R.J. Davis, J.D. Wiens, G.C. White, J.D. Nichols, J.E. Hines, C.B. Yackulic, C.J. Schwarz, S.H. Ackers, L.S. Andrews, L.L. Bailey, R. Bown, J. Burgher, K.P. Burnham, P.C. Carlson, T. Chestnut, M.M. Conner, K.E. Dilione, E.D. Forsman, E.M. Glenn, S.A. Gremel, K.A. Hamm, D.R. Herter, J.M. Higley, R.B. Horn, J.M. Jenkins, W.L. Kendall, D.W. Lamphear, C. McCafferty, T.L. McDonald, J.A. Reid, J.T. Rockweit, D.C. Simon, S.G. Sovern, J.K. Swingle, and H. Wise. 2021. Range-wide declines of northern spotted owl populations in the Pacific Northwest: A meta-analysis. Biological Conservation 259: 109168. https://doi.org/10.1016/j.biocon.2021.109168.

Franklin, J.F., and D.C. Donato. 2020. Variable retention harvesting in the Douglasfir region. Ecological Processes 9 (1): 8. https://doi.org/10.1186/s13717-019-02 05-5.

Franklin, J.F., and C.T. Dyrness. 1973. Natural Vegetation of Oregon and Washington vol General Technical Report PNW-8. Portland: USDA Forest Service, Pacific Northwest Forest and Range Experiment Station.

Franklin, J.F., and M.A. Hemstrom. 1981. Aspects of succession in the coniferous forests of the Pacific Northwest. In Forest Succession: Concepts and Application, ed. D.C. West, H.H. Shugart, and D.B. Botkin, 212-229. New York: Springer-Verlag. https://doi.org/10.1007/978-1-4612-5950-3_14.

Frey, S.J.K., A.S. Hadley, S.L. Johnson, M. Schulze, J.A. Jones, and M.G. Betts. 2016 Spatial models reveal the microclimatic buffering capacity of old-growth forests. Science Advances 2 (4): e1501392. https://doi.org/10.1126/sciadv.15013 92.

Ganey, J.L., H.Y. Wan, S.A. Cushman, and C.D. Vojta. 2017. Conflicting perspectives on spotted owls, wildfire, and forest restoration. Fire Ecology 13 (3) in press: 146-165. https://doi.org/10.4996/fireecology.130318020.

Gorelick, N., M. Hancher, M. Dixon, S. Ilyushchenko, D. Thau, and R. Moore. 2017. Google Earth Engine: Planetary-scale geospatial analysis for everyone. Remote Sensing of Environment 202: 18-27. https://doi.org/10.1016/j.rse.2017.06.031.

Hagmann, R.K., J.F. Franklin, and K.N. Johnson. 2014. Historical conditions in mixed-conifer forests on the eastern slopes of the northern Oregon Cascade Range, USA. Forest Ecology and Management 330: 158-170. https://doi.org/1 0.1016/j.foreco.2014.06.044.

Hagmann, R.K., D.L. Johnson, and K.N. Johnson. 2017. Historical and current forest conditions in the range of the Northern Spotted Owl in south central Oregon, USA. Forest Ecology and Management 389: 374-385. https://doi.org/1 0.1016/j.foreco.2016.12.029.

Hagmann, R.K., A.G. Merschel, and M.J. Reilly. 2019. Historical patterns of fire severity and forest structure and composition in a landscape structured by frequent large fires: Pumice Plateau ecoregion, Oregon, USA. Landscape Ecology 34 (3): 551-568. https://doi.org/10.1007/s10980-019-00791-1.

Halofsky, J.E., D.C. Donato, D.E. Hibbs, J.L. Campbell, M.D. Cannon, J.B. Fontaine, J. R. Thompson, R.G. Anthony, B.T. Bormann, L.J. Kayes, B.E. Law, D.L. Peterson, and T.A. Spies. 2011. Mixed-severity fire regimes: lessons and hypotheses 
from the Klamath-Siskiyou Ecoregion. Ecosphere 2 (4): art40. https://doi.org/1 0.1890/es10-00184.1.

Halofsky, J.E., D.L. Peterson, and B.J. Harvey. 2020. Changing wildfire, changing forests: the effects of climate change on fire regimes and vegetation in the Pacific Northwest, USA. Fire Ecology 16 (1). https://doi.org/10.1186/s42408-01 9-0062-8.

Hanson, C.T., D.C. Odion, D.A. Dellasala, and W.L. Baker. 2009. Overestimation of fire risk in the northern spotted owl recovery plan. Conservation Biology 23 (5): 1314-1319. https://doi.org/10.1111/j.1523-1739.2009.01265.x.

Healey, S.P., W.B. Cohen, Z. Yang, C. Kenneth Brewer, E.B. Brooks, N. Gorelick, A.J. Hernandez, C. Huang, M. Joseph Hughes, R.E. Kennedy, T.R. Loveland, G.G. Moisen, T.A. Schroeder, S.V. Stehman, J.E. Vogelmann, C.E. Woodcock, L. Yang, and Z. Zhu. 2018. Mapping forest change using stacked generalization: An ensemble approach. Remote Sensing of Environment 204: 717-728. https:// doi.org/10.1016/j.rse.2017.09.029.

Healey, S.P., W.B. Cohen, Y. Zhiqiang, K. Brewer, E. Brooks, N. Gorelick, M. Gregory, A. Hernandez, C. Huang, J. Hughes, R. Kennedy, T. Loveland, K. Megown, G. Moisen, T. Schroeder, B. Schwind, S. Stehman, D. Steinwand, J. Vogelmann, C. Woodcock, L. Yang, and Z. Zhu. 2015. Next-generation forest change mapping across the United States: the landscape change monitoring system (LCMS). In Pushing boundaries: new directions in inventory techniques and applications: Forest Inventory and Analysis (FIA) symposium 2015. 2015 December 8-10; Portland, Oregon. Gen. Tech. Rep. PNW-GTR-931, vol PNW-GTR931, ed. S.M. Stanton and G.A. Christensen. Portland: USDA Forest Service, Pacific Northwest Research Station

Heithecker, T.D., and C.B. Halpern. 2007. Edge-related gradients in microclimate in forest aggregates following structural retention harvests in western Washington. Forest Ecology and Management 248 (3): 163-173. https://doi. org/10.1016/j.foreco.2007.05.003.

Herring, M., and S. Greene. 2001. Forest of time: Research at the Wind River Experimental Forest 1908-1919. In Forest History Today Spring/Fall, 36-43.

Heyerdahl, E.K., L.B. Brubaker, and J.K. Agee. 2001. Spatial controls of historical fire regimes: a multiscale example from the interior west, USA. Ecology 82 (3): 660-678. https://doi.org/10.1890/0012-9658(2001)082[0660:SCOHFR]2.0.CO;2.

Higuera, P.E., and J.T. Abatzoglou. 2020. Record-setting climate enabled the extraordinary 2020 fire season in the western United States. Global Change Biology 27 (1): 1-2. https://doi.org/10.1111/gcb.15388.

Hirzel, A.H., G. Le Lay, V. Helfer, C. Randin, and A. Guisan. 2006. Evaluating the ability of habitat suitability models to predict species presences. Ecological Modelling 199 (2): 142-152. https://doi.org/10.1016/..ecolmodel.2006.05.017.

Hursh, C.R., and C.A. Connaughton. 1938. Effects of forests on local climate. Journal Of Forestry 36: 864-866.

Hutto, R.L. 2008. The ecological imporance of severe wildfires: Some like it hot. Ecological Applications 18 (8): 1827-1834. https://doi.org/10.1890/08-0895.1.

Jenkins, J.M.A., D.B. Lesmeister, E.D. Forsman, K.M. Dugger, S.H. Ackers, L.S. Andrews, S.A. Gremel, B. Hollen, C.E. McCafferty, M.S. Pruett, J.A. Reid, S.G. Sovern, and J.D. Wiens. 2021. Conspecific and congeneric interactions shape increasing rates of breeding dispersal of northern spotted owls. Ecological Applications early online: e02398. https://doi.org/10.1002/eap.2398.

Jenkins, J.M.A., D.B. Lesmeister, E.D. Forsman, K.M. Dugger, S.H. Ackers, L.S. Andrews, C.E. McCafferty, M.S. Pruett, J.A. Reid, S.G. Sovern, R.B. Horn, S.A. Gremel, J.D. Wiens, and Z. Yang. 2019a. Social status, forest disturbance, and Barred Owls shape long-term trends in breeding dispersal distance of Northern Spotted Owls. The Condor 121 (4): duz055. https://doi.org/10.1093/ condor/duz055

Jenkins, J.M.A., D.B. Lesmeister, J.D. Wiens, J.T. Kane, V.R. Kane, and J. Verschuyl. 2019b. Three-dimensional partitioning of resources by congeneric forest predators with recent sympatry. Scientific Reports 9 (1): 6036. https://doi.org/1 0.1038/s41598-019-42426-0

Jones, G.M., R.J. Gutièrrez, W.M. Block, P.C. Carlson, E.J. Comfort, S.A. Cushman, R.J. Davis, S.A. Eyes, A.B. Franklin, J.L. Ganey, S. Hedwall, J.J. Keane, R. Kelsey, D.B. Lesmeister, M.P. North, S.L. Roberts, J.T. Rockweit, J.S. Sanderlin, S.C. Sawyer, B. Solvesky, D.J. Tempel, H.Y. Wan, A.L. Westerling, G.C. White, and M.Z. Peery. 2020a. Spotted owls and forest fire: comment. Ecosphere 11 (12): e03312. https://doi.org/10.1002/ecs2.3312.

Jones, G.M., R.J. Gutiérrez, D.J. Tempel, S.A. Whitmore, W.J. Berigan, and M.Z. Peery. 2016. Megafires: an emerging threat to old-forest species. Frontiers in Ecology and the Environment 14 (6): 300-306. https://doi.org/10.1002/fee.12 98.

Jones, G.M., H.A. Kramer, S.A. Whitmore, W.J. Berigan, D.J. Tempel, C.M. Wood, B.K. Hobart, T. Erker, F.A. Atuo, N.F. Pietrunti, R. Kelsey, R.J. Gutiérrez, and M.Z.
Peery. 2020b. Habitat selection by spotted owls after a megafire reflects their adaptation to historical frequent-fire regimes. Landscape Ecology 35 (5): 1199-1213. https://doi.org/10.1007/s10980-020-01010-y.

Kalies, E.L., and L.L. Yocom Kent. 2016. Tamm Review: Are fuel treatments effective at achieving ecological and social objectives? A systematic review. Forest Ecology and Management 375: 84-95. https://doi.org/10.1016/j.foreco.2 016.05.021.

Keyser, A.R., and A.L. Westerling. 2019. Predicting increasing high severity area burned for three forested regions in the western United States using extreme value theory. Forest Ecology and Management 432: 694-706. https:// doi.org/10.1016/j.foreco.2018.09.027.

Kitzberger, T., E. Araoz, J.H. Gowda, M. Mermoz, and J.M. Morales. 2012. Decreases in fire spread probability with forest age promotes alternative community states, reduced resilience to climate variability and large fire regime shifts. Ecosystems 15 (1): 97-112. https://doi.org/10.1007/s10021-011-9494-y).

Kramer, A., G.M. Jones, S.A. Whitmore, J.J. Keane, F.A. Atuo, B.P. Dotters, S.C. Sawyer, S.L. Stock, R.J. Gutiérrez, and M.Z. Peery. 2021. California spotted owl habitat selection in a fire-managed landscape suggests conservation benefit of restoring historical fire regimes. Forest Ecology and Management: 479. https://doi.org/10.1016/j.foreco.2020.118576.

Lesmeister, D.B., R.J. Davis, P.H. Singleton, and J.D. Wiens. 2018. Northern spotted owl habitat and populations: status and threats. In Synthesis of Science to Inform Land Management within the Northwest Forest Plan Area. PNW-GTR966, vol 1, ed. T.A. Spies, P.A. Stine, R. Gravenmier, J.W. Long, and M.J. Reilly, 245-298. Portland: USDA Forest Service, Pacific Northwest Research Station.

Lesmeister, D.B., S.G. Sovern, R.J. Davis, D.M. Bell, M.J. Gregory, and J.C. Vogeler. 2019. Mixed-severity wildfire and habitat of an old-forest obligate. Ecosphere 10 (4): e02696. https://doi.org/10.1002/ecs2.2696.

Maillard, O., R. Vides-Almonacid, M. Flores-Valencia, R. Coronado, P. Vogt, S.M. Vicente-Serrano, H. Azurduy, R. Anívarro, and R.L. Cuellar. 2020. Relationship of forest cover fragmentation and drought with the occurrence of forest fires in the Department of Santa Cruz, Bolivia. Forests 11 (9): 910. https://doi.org/1 0.3390/f11090910.

Manly, B.F.J., L.L. McDonald, D.L. Thomas, T.L. McDonald, and W.P. Erickson. 2002. Resource Selection by Animals: Statistical Design and Analysis for Field Studies. 2nd ed. Dordrecht: Kluwer Academic Publishers.

Marlon, J.R. 2020. What the past can say about the present and future of fire. Quaternary Research 96: 66-87. https://doi.org/10.1017/qua.2020.48.

Martin, R.E., D.D. Robinson, and W.H. Schaeffer. 1974. Fire in the Pacific Northwest: Perspectives and problems. Proceedings of the Annual Tall Timbers Fire Ecology Conference 15: 1-23.

Martinson, E.J., and P.N. Omi. 2013. Fuel treatments and fire severity: a metaanalysis. Research Paper RMRS-RP-103WWW. Fort Collin: USDA Forest Service, Rocky Mountain Research Station. https://doi.org/10.2737/RMRS-RP-103.

Mass, C. 2020. An Important Finding about the September Labor Day Wildfires. Vol. 2021.

McKenzie, D., Z. Gedalof, D.L. Peterson, and P. Mote. 2004. Climatic change, wildfire, and conservation. Conservation Biology 18 (4): 890-902. https://doi. org/10.1111/j.1523-1739.2004.00492.x.

Meddens, A.J.H., C.A. Kolden, J.A. Lutz, A.M.S. Smith, C.A. Cansler, J.T. Abatzoglou, G.W. Meigs, W.M. Downing, and M.A. Krawchuk. 2018. Fire refugia: what are they, and why do they matter for global change? BioScience 68: 944-954. https://doi.org/10.1093/biosci/biy103.

Meigs, G., and M. Krawchuk. 2018. Composition and structure of forest fire refugia: what are the ecosystem legacies across burned landscapes? Forests 9 (5): f9050243. https://doi.org/10.3390/f9050243.

Meigs, G.W., C.J. Dunn, S.A. Parks, and M.A. Krawchuk. 2020. Influence of topography and fuels on fire refugia probability under varying fire weather in forests of the US Pacific Northwest. Canadian Journal of Forest Research early online: 50 (7): 1-39. https://doi.org/10.1139/cjfr-2019-0406.

Miller, J.D., and A.E. Thode. 2007. Quantifying burn severity in a heterogeneous landscape with a relative version of the delta Normalized Burn Ratio (dNBR). Remote Sensing of Environment 109 (1): 66-80. https://doi.org/10.1016/j.rse.2 006.12.006.

Miller, M.P., S.M. Haig, E.D. Forsman, R.G. Anthony, L. Diller, K.M. Dugger, A.B. Franklin, T.L. Fleming, S. Gremel, D.B. Lesmeister, M. Higley, D.R. Herter, and S. G. Sovern. 2018. Variation in inbreeding rates across the range of Northern Spotted Owls (Strix occidentalis caurina): Insights from over 30 years of monitoring data. The Auk 135 (4): 821-833. https://doi.org/10.1642/auk-18-1.1.

Moreira, F. F.C. Rego, and P.G. Ferreira. 2001. Temporal (1958-1995) pattern of change in a cultural landscape of northwestern Portugal: implications for fire 
occurrence. Landscape Ecology 16 (6): 557-567. https://doi.org/10.1023/A:1 013130528470.

Moreira, F., P. Vaz, F. Catry, and J.S. Silva. 2009. Regional variations in wildfire susceptibility of land-cover types in Portugal: implications for landscape management to minimize fire hazard. International Journal ofWildland Fire 18 (5): 563-574. https://doi.org/10.1071/WF07098.

Moritz, M.A., T.J. Moody, M.A. Krawchuk, M. Hughes, and A. Hall. 2010. Spatial variation in extreme winds predicts large wildfire locations in chaparral ecosystems. Geophysical Research Letters 37 (4): L04801. https://doi.org/10.102 9/2009gl041735.

Ohmann, J.L., and M.J. Gregory. 2002. Predictive mapping of forest composition and structure with direct gradient analysis and nearest- neighbor imputation in coastal Oregon, U.S.A. Canadian Journal of Forest Research 32 (4): 725-741. https://doi.org/10.1139//X02-011

Oliver, C.D. 1981. Forest development in North America following major disturbances. Forest Ecology and Management 3: 153-168. https://doi.org/10.1 016/0378-1127(80)90013-4.

Phillips, S.J., R.P. Anderson, M. Dudík, R.E. Schapire, and M.E. Blair. 2017. Opening the black box: an open-source release of Maxent. Ecography 40 (7): 887-893. https://doi.org/10.1111/ecog.03049.

Phillips, S.J., R.P. Anderson, and R.E. Schapire. 2006. Maximum entropy modeling of species geographic distributions. Ecological Modelling 190 (3-4): 231-259. https://doi.org/10.1016/j.ecolmodel.2005.03.026.

Pickrell, J., and E. Pennisi. 2020. Record U.S. and Australian fires raise fears for many species. Science 370 (6512): 18-19. https://doi.org/10.1126/science.370 6512.18

Potter, B.E. 2012. Atmospheric interactions with wildland fire behaviour - I. Basic surface interactions, vertical profiles and synoptic structures. International Journal of Wildland Fire 21 (7): 779-801. https://doi.org/10.1071/wf11128.

Prichard, S.J., N.A. Povak, M.C. Kennedy, and D.W. Peterson. 2020. Fuel treatment effectiveness in the context of landform, vegetation, and large, wind-driven wildfires. Ecological Applications 30 (5): e02104. https://doi.org/10.1002/eap.21 04.

Reilly, M.J., C.J. Dunn, G.W. Meigs, T.S. Spies, R.E. Kennedy, J.D. Bailey, and K. Briggs. 2017. Contemporary patterns of fire extent and severity in forests of the Pacific Northwest, USA (1985-2010). Ecosphere 8 (3): e01695. https://doi. org/10.1002/ecs2.1695.

Reinhardt, E.D., R.E. Keane, D.E. Calkin, and J.D. Cohen. 2008. Objectives and considerations for wildland fuel treatment in forested ecosystems of the interior western United States. Forest Ecology and Management 256 (12): 1997-2006. https://doi.org/10.1016/j.foreco.2008.09.016.

Rockweit, J.T., A.B. Franklin, and P.C. Carlson. 2017. Differential impacts of wildfire on the population dynamics of an old-forest species. Ecology 98 (6): 15741582. https://doi.org/10.1002/ecy.1805.

Schoennagel, T., J.K. Balch, H. Brenkert-Smith, P.E. Dennison, B.J. Harvey, M.A. Krawchuk, N. Mietkiewicz, P. Morgan, M.A. Moritz, R. Rasker, M.G. Turner, and C. Whitlock. 2017. Adapt to more wildfire in western North American forests as climate changes. Proceedings of the National Academy of Sciences U S A 114 (18): 4582-4590. https://doi.org/10.1073/pnas.1617464114.

Silva Junior, C.H.L., Aragão, M. Fonseca, C. Almeida, L. Vedovato, and L. Anderson. 2018. Deforestation-Induced Fragmentation Increases Forest Fire Occurrence in Central Brazilian Amazonia. Forests 9 (6): 305. https://doi.org/10.3390/ f9060305.

da Silva, S.S., P.M. Fearnside, P.M.L. de Alencastro Graça, I.F. Brown, A. Alencar, and Antonio Willian Flores de Melo. 2018. Dynamics of forest fires in the southwestern Amazon. Forest Ecology and Management 424: 312-322. https://doi.org/10.1016/j.foreco.2018.04.041.

Smith, J.K., ed. 2000. Wildland fire in ecosystems: effects of fire on fauna. vol RMRSGTR-42. Ogden: U.S. Department of Agriculture, Forest Service, Rocky Mountain Research Station. https://doi.org/10.2737/RMRS-GTR-42-V1.

Soille, P., and P. Vogt. 2009. Morphological segmentation of binary patterns. Pattern Recognition Letters 30 (4): 456-459. https://doi.org/10.1016/j.patrec.2 008.10.015.

Sovern, S.G., D.B. Lesmeister, K.M. Dugger, M.S. Pruett, R.J. Davis, and J.M. Jenkins. 2019. Activity center selection by northern spotted owls. Journal of Wildlife Management 83 (3): 714-727. https://doi.org/10.1002/jwmg.21632.

Spies, T.A., P.F. Hessburg, C.N. Skinner, K.J. Puettmann, M.J. Reilly, R.J. Davis, J.A. Kertis, J.W. Long, and D.C. Shaw. 2018. Chapter 3: Old growth, disturbance, forest succession, and management in the area of the Northwest Forest Plan. In Synthesis of science to inform land management within the Northwest Forest Plan area. Gen. Tech. Rep. PNW-GTR-966, ed. T.A. Spies, P.A. Stine, R.
Gravenmier, J.W. Long, and M.J. Reilly, 95-243. Portland: U.S. Department of Agriculture, Forest Service, Pacific Northwest Research Station.

Spies, T.A., J.W. Long, S. Charnley, P.F. Hessburg, B.G. Marcot, G.H. Reeves, D.B. Lesmeister, M.J. Reilly, L.K. Cerveny, P.A. Stine, and M.G. Raphael. 2019. Twenty-five years of the Northwest Forest Plan: what have we learned? Frontiers in Ecology and the Environment 17 (9): 511-520. https://doi.org/10.1 002/fee.2101.

Spies, T.A., J.D. Miller, J.B. Buchanan, J.F. Lehmkuhl, J.F. Franklin, S.P. Healey, P.F. Hessburg, H.D. Safford, W.B. Cohen, R.S. Kennedy, E.E. Knapp, J.K. Agee, and M. Moeur. 2010. Underestimating risks to the northern spotted owl in fireprone forests: response to Hanson et al. Conservation Biology 24 (1): 330-333; discussion 334-337. https://doi.org/10.1111/j.1523-1739.2009.01414.x.

Stone, C., A. Hudak, and P. Morgan. 2003. Forest harvest can increase subsequent forest fire severity. In Proceedings of the second international symposium on fire economics, planning, and policy: a global view. Gen. Tech. Rep. PSW-GTR208, ed. A. González-Cabán. Albany: USDA Forest Service, Pacific Southwest Research Station. https://doi.org/10.2737/PSW-GTR-208.

Sugihara, N.G., J.W. van Wagtendonk, and J.A. Fites-Kaufman. 2018. Fire as an ecological process. In Fire in California's Ecosystems, ed. J.W. van Wagtendonk, N.G. Sugihara, S.L. Stephens, A.E. Thode, K.E. Shaffer, and J. Fites-Kaufman, 2nd ed. Berkeley: University of California Press.

Swanson, M.E., J.F. Franklin, R.L. Beschta, C.M. Crisafulli, D.A. DellaSala, R.L. Hutto, D.B. Lindenmayer, and F.J. Swanson. 2011. The forgotten stage of forest succession: early-successional ecosystems on forest sites. Frontiers in Ecology and the Environment 9 (2): 117-125. https://doi.org/10.1890/090157.

Thode, A.E., J.W. Van Wagtendonk, J.D. Miller, and J.F. Quinn. 2011. Quantifying the fire regime distributions for severity in Yosemite National Park, California, USA. International Journal of Wildland Fire 20 (2): 223-239. https://doi.org/10.1 071/NF09060.

Thompson, J.R., and T.A. Spies. 2009. Vegetation and weather explain variation in crown damage within a large mixed-severity wildfire. Forest Ecology and Management 258 (7): 1684-1694. https://doi.org/10.1016/j.foreco.2009.07.031.

Thompson, J.R., and T.A. Spies. 2010. Factors associated with crown damage following recurring mixed-severity wildfires and post-fire management in southwestern Oregon. Landscape Ecology 25 (5): 775-789. https://doi.org/10.1 007/s10980-010-9456-3.

Thompson, J.R., T.A. Spies, and L.M. Ganio. 2007. Reburn severity in managed and unmanaged vegetation in a large wildfire. Proceedings of the National Academy of Sciences 104 (25): 10743-10748. https://doi.org/10.1073/pnas. 0700229104.

USDA, and USDI. 1994. Final Supplemental Environmental Impact Statement on Management of Habitat for Late-Successional and Old-Growth Forest Related Species Within the Range of the Northern Spotted OwI. Portland: USDA Forest Service and USDI Bureau of Land Management.

USFWS. 1990. Endangered and threatened wildlife and plants: determination of threatened status for the northern spotted owl. Federal Register 55 (123): 26114-26194.

USFWS. 2011. Revised Recovery Plan for the Northern Spotted Owl (Strix occidentalis caurina). Portland: USDI Fish and Wildlife Service.

USFWS. 2015. Endangered and threatened wildlife and plants; 12-month findings for petitions to list the greater sage-grouse (Centrocercus urophasianus) as threatened or endangered. Federal Register 80: 59857-59942.

USFWS. 2020. Endangered and Threatened Wildlife and Plants: 12-Month Finding for the Northern Spotted Owl. Federal Register 85 (241): 81144-81152.

Ustin, S.L., D. Riaño, A. Koltunov, D.A. Roberts, and P.E. Dennison. 2009. Mapping fire risk in mediterranean ecosystems of California: Vegetation type, density, invasive species, and fire frequency. In Earth Observation of Wildland Fires in Mediterranean Ecosystems, ed. E. Chuvieco, 41-53. Heidelberg: Springer. https://doi.org/10.1007/978-3-642-01754-4_4.

van Wagtendonk, J.W., and J. Fites-Kaufman. 2006. Sierra Nevada bioregion. In Fire in California's Ecosystems, ed. N.G. Sugihara, J.W. van Wagtendonk, J. FitesKaufman, K.E. Shaffer, and A.E. Thode. Berkeley: University of California Press. https://doi.org/10.1525/california/9780520246058.003.0012.

Walsh, M.K., J.R. Marlon, S.J. Goring, KJ. Brown, and D.G. Gavin. 2015. A regional perspective on holocene fire-climate-human interactions in the Pacific Northwest of North America. Annals of the Association of American Geographers 105 (6): 1135-1157. https://doi.org/10.1080/00045608.2015.1064457.

Wan, H.Y., S.A. Cushman, and J.L. Ganey. 2019. Recent and projected future wildfire trends across the ranges of three spotted owl subspecies under climate change. Frontiers in Ecology and Evolution 7: 37. https://doi.org/10.33 89/fevo.2019.00037. 
Wan, H.Y., S.A. Cushman, and J.L. Ganey. 2020. The effect of scale in quantifying fire impacts on species habitats. Fire Ecology 16 (1). https://doi.org/10.1186/ s42408-020-0068-2.

Weatherspoon, C.P., and C.N. Skinner. 1995. An assessment of factors associated with damage to tree crowns from the 1987 wildfires in northern California. Forest Science 41 (3): 430-451. https://doi.org/10.1093/forestscience/41.3.430

Westerling, A.L., H.G. Hidalgo, D.R. Cayan, and T.W. Swetnam. 2006. Warming and earlier spring increase western U.S. forest wildfire activity. Science 313 (5789): 940-943. https://doi.org/10.1126/science.1128834.

Wiens, J.D., R.G. Anthony, and E.D. Forsman. 2014. Competitive interactions and resource partitioning between northern spotted owls and barred owls in Western Oregon. Wildlife Monographs 185 (1): 1-50. https://doi.org/10.1002/ wmon.1009.

Wiens, J.D., K.E. Dilione, C.A. Eagles-Smith, G. Herring, D.B. Lesmeister, M.W. Gabriel, G.M. Wengert, and D.C. Simon. 2019. Anticoagulant rodenticides in Strix owls indicate widespread exposure in west coast forests. Biological Conservation 238: 108238. https://doi.org/10.1016/j.biocon.2019.108238.

Wiens, J.D., K.M. Dugger, J.M. Higley, D.B. Lesmeister, A.B. Franklin, K.A. Hamm, G. C. White, K.E. Dilione, D.C. Simon, R.R. Bown, P.C. Carlson, C.B. Yackulic, J.D. Nichols, J.E. Hines, R.J. Davis, D.W. Lamphear, C. McCafferty, T.L. McDonald, and S.G. Sovern. 2021. Invader removal triggers competitive release in a threatened avian predator. Proceedings of the National Academy of Sciences 118 (31): e2102859118. https://doi.org/10.1073/pnas.2102859118.

Wilk, R.J., D.B. Lesmeister, and E.D. Forsman. 2018. Nest trees of northern spotted owls (Strix occidentalis caurina) in Washington and Oregon, USA. Plos One 13 (5): e0197887. https://doi.org/10.1371/journal.pone.0197887.

Yackulic, C.B., L.L. Bailey, K.M. Dugger, R.J. Davis, A.B. Franklin, E.D. Forsman, S.H. Ackers, L.S. Andrews, L.V. Diller, S.A. Gremel, K.A. Hamm, D.R. Herter, M. Higley, R.B. Horn, C. McCafferty, J.A. Reid, J.R. Rockweit, and S.G. Sovern. 2019. The past and future roles of competition and habitat in the rangewide occupancy dynamics of Northern Spotted Owls. Ecological Applications 29 (3): e01861. https://doi.org/10.1002/eap.1861.

Zald, H.S.J., and C.J. Dunn. 2018. Severe fire weather and intensive forest management increase fire severity in a multi-ownership landscape. Ecological Applications 28 (4): 1068-1080. https://doi.org/10.1002/eap.1710.

Zyback, B. 2004. The great fires: Indian burning and catastrophic forest fire patterns of the Oregon Coast Range, 1491-1951. Corvallis: Oregon State University.

\section{Publisher's Note}

Springer Nature remains neutral with regard to jurisdictional claims in published maps and institutional affiliations.

\section{Submit your manuscript to a SpringerOpen ${ }^{\circ}$ journal and benefit from:}

- Convenient online submission

- Rigorous peer review

- Open access: articles freely available online

- High visibility within the field

- Retaining the copyright to your article

Submit your next manuscript at $\boldsymbol{\nabla}$ springeropen.com 